\title{
Evolutionary Overview and Prediction of Themes in the Field of Land Degradation
}

\author{
Xinhai Lu ${ }^{1,2,+}$, Yanwei Zhang ${ }^{1,+} \mathbb{C}$, Chaoran Lin ${ }^{3,4, * \mathbb{D}}$ and Feng $\mathrm{Wu}^{1}$ \\ 1 College of Public Administration, Huazhong University of Science and Technology, Wuhan 430074, China; \\ luxinhai@hust.edu.cn (X.L.); bsonyan@hust.edu.cn (Y.Z.); d201981173@hust.edu.cn (F.W.) \\ 2 College of Public Administration, Central China Normal University, Wuhan 430079, China \\ 3 College of Computer Science and Technology, Harbin Engineering University, Harbin 150001, China \\ 4 School of Economics and Management, Harbin Engineering University, Harbin 150001, China \\ * Correspondence: linchaoran@hrbeu.edu.cn \\ + These authors contributed equally to this work.
}

check for

updates

Citation: Lu, X.; Zhang, Y.; Lin, C.; Wu, F. Evolutionary Overview and Prediction of Themes in the Field of Land Degradation. Land 2021, 10, 241. https://doi.org/10.3390/land10030241

Academic Editors: Agata Novara

Received: 19 January 2021

Accepted: 23 February 2021

Published: 1 March 2021

Publisher's Note: MDPI stays neutral with regard to jurisdictional claims in published maps and institutional affiliations.

Copyright: (c) 2021 by the authors. Licensee MDPI, Basel, Switzerland. This article is an open access article distributed under the terms and conditions of the Creative Commons Attribution (CC BY) license (https:/ / creativecommons.org/licenses/by/ $4.0 /)$.

\begin{abstract}
Land degradation has become one of the major global environmental problems threatening human well-being. Whether degraded land can be restored has a profound effect on the achievement of the 2030 UN Sustainable Development Goals. Therefore, the ways by which to identify the current research status and potential research topics in the massive scientific literature data in the field of land degradation is a crucial issue for scientific research institutions in various countries. In view of the shortcomings in the current research on the thematic evolution and thematic and thematic prediction, such as the ignorance of random features during scientific innovation, the defects of manual classification, and the difficulty of identifying technical terms, this research proposes a new combined method. First, the Latent Dirichlet Allocation (LDA) algorithm in machine learning is used to capture the potential clustering of themes in the literature sample set of land degradation research. The distribution characteristics and evolution of themes in each period are then analyzed. The method is combined with the Hidden Markov Model (HMM), which contains double stochastic process to quantitatively predict the trend of future thematic evolution. Finally, the above-mentioned combined method is used to analyze the evolution characteristics and future development trends of the themes in the field of land degradation. Comparative experiments show that the method in this study is effective and practical. The research results show that rangeland degradation, surface temperature, island, soil degradation, water quality, crop productivity and restoration are important research topics in the field of land degradation in the future. In addition, based on the advantages of this model, this model can be widely used in the thematic evolution and prediction analysis of different research fields in land use science.
\end{abstract}

Keywords: land degradation; latent Dirichlet allocation; hidden Markov model; thematic evolution; thematic prediction

\section{Introduction}

Land degradation is not only a serious ecological and environmental problem but also a global social issue that causes poverty and hinders the sustainable development of the society [1]. According to relevant data released by Intergovernmental Science-Policy Platform on Biodiversity and Ecosystem Services (IPBES), human intervention has caused approximately $80 \%$ of agricultural land, $10-20 \%$ of pastures, and $87 \%$ of wetlands around the world to be severely degraded [2]. Land degradation is prevalent in all countries, land use types, and landscape types [3]. The problems caused by the loss of biodiversity [4], food and energy security [5], environmental pollution [6], and the sustainable development of the socio-economic system [7] have directly or indirectly affected the welfare and basic benefit of approximately 3.2 billion people worldwide $[8,9]$. 
To alleviate and improve land degradation on a global scale, United Nations Convention to Combat Desertification (UNCCD) proposed the new concept of Land Degradation Neutrality (LDN) in 2015 on the basis of the Zero Net Land Degradation goal. The concept aims to achieve the goal of maintaining the ecosystem service function and value by ensuring the quantity and quality of productive land [10]. On this basis, the UN 2030 Sustainable Development Goals (SDGs) have clearly listed "containing, reversing and restoring land degradation and slowing down economic growth at the expense of environmental degradation" as its 15th goal [11]. However, human demand for land resources is constantly increasing at this stage. According to Intergovernmental Science-Policy Platform on Biodiversity and Ecosystem Services (IPBES) forecasts [12,13], the two factors of land degradation and climate change will reduce the average global crop yield by an average of $10 \%$ by 2050 and even $50 \%$ in some regions. Moreover, these two factors may force large-scale population transfers around the world, trigger social conflicts, and affect world stability. Therefore, the health status of land resources must be fully understood, and analysis and research on the driving factors of land degradation must be carried out. Furthermore, the threats faced by the ecosystem must be determined, and model methods for predicting its future change trends must be used $[14,15]$. These tasks are of great significance for global biodiversity conservation, maintaining the balance of ecosystems, and enhancing human well-being [16]. On this basis, scholars have carried out extensive research in terms of the following: clarifying the mechanism of land degradation [17], strengthening the research and development of land degradation monitoring technology [18], speeding up the formulation of land degradation prevention and control policies [19], and promoting the ecological restoration and reconstruction of degraded land [20]. The terms involved in this article and their meanings can be found in Table 1 (Appendix A).

Scientific literature contains the research results of human wisdom and also reflects the evolutionary process of technological development. At present, scholars have qualitatively combed the literature in the field of land degradation. For example, Oliveira believes that preventing and reversing land degradation requires strong land use management policies, as well as effective spatial planning mechanisms. Therefore, Oliveira reviewed the strategic spatial planning literature published from 1992 to 2017 in order to explore the mechanism of strategic spatial planning to reduce land degradation. The research results show that the current sustainable development and environmental issues have become the core issues for strategic spatial planning in recent years [21]. However, it rarely involves the governance of land degradation. Therefore, in the future, governments should formulate corresponding strategic spatial planning and land use policies for global land degradation phenomena. Halbac-Cotoara-Zamfir pointed out that in the Mediterranean region without extreme ecological conditions, land degradation is still very serious. Therefore, Halbac-CotoaraZamfir discussed the performance of southern European land use policies in reducing land degradation. The results of the study show that development policies that indirectly address land degradation have shown to be an important carrier for more specific measures to reduce the risk of desertification, thus creating a favorable environment for direct intervention to mitigate or adapt to climate change [22]. However, qualitative analysis of the changes in the research hotspots in the field of land degradation lacks accurate judgment. Therefore, research on the thematic evolution and prediction of scientific literature in the field of land degradation can help scholars fully understand its historical evolution and future trends and find the breakthrough. This work can provide references for the research layout of scientific research institutions in various countries. Therefore, the study of thematic evolution prediction is of great significance to the field of land degradation. At present, several scholars have used different methods to analyze research themes in the field of land degradation. Xie used Sankey diagram to analyze the evolution of research themes in the field of land degradation from 1990 to 2019 on the basis of co-word analysis. The research results show that the evolutionary relationship of themes in the field of land degradation in various periods is complex and unstable [23]. Escadafal conducted a social network analysis of the key words contained in scientific literature in the field of land 
degradation. The research results show that the keyword "Land" has a closer relationship with the humanities and social sciences (such as sociology, anthropology, economics, and public administration science). The keyword "Soil" is closely related to natural science (such as microbiology, biotechnology, optics, and astronomy) [24]. However, most of the above-mentioned studies focus on co-word analytical method. The co-word analytical method is improved on the basis of word frequency analysis by using a co-word matrix for clustering and strategic diagram or cluster network map to reflect the correlation between themes [25]. However, several problems prevail in the selection of themes compared with topic model. These problems include strong subjectivity, difficulty in determining the dividing point between high-frequency and low-frequency words, and complications in reflecting the deeper semantic relationship between themes.

In recent years, scholars have used the Latent Dirichlet Allocation (LDA) model for thematic research in the field of bibliometrics to solve the above-mentioned problems and achieved good results. The dimensionality of the text can be reduced, and dimensional disasters can be avoided when the LDA model is applied to massive heterogeneous text data. At present, scholars of different disciplines have widely used the LDA model in scientific literature in the fields of biomedicine [26], computer linguistics [27], economics [28], and library information management [29], automatically mining research themes in a large number of literature and understanding research trends in a certain field.

However, most current bibliometric studies focus on the analysis of the status quo in a certain field and are mostly subjective interpretation. Relatively few studies have been conducted on topic prediction. The manner by which to integrate the internal and external characteristics of scientific literature and construct a rigorous model to effectively predict the future trend of research themes needs to be extensively studied. At present, scholars generally use gray forecasting method [30], life cycle method [31], time series analysis [32], and neural network forecasting methods [33] for forecasting research. However, randomness is an essential phenomenon during innovation. These research methods generally ignore the random nature of innovation. In the quantitative prediction of the evolution trend of the themes of land degradation, the continuity of existing themes will be overestimated, and the explosive growth of new themes will be underestimated if randomness is ignored. Hidden Markov Model (HMM) is a double random process. The transition between states and the observed values of states are random. Therefore, HMM is a probabilistic model that can describe the uncertainty of state transition. However, no research has applied HMM to quantitative prediction research on the themes of land degradation research.

This study proposes a combined method to solve the above-mentioned problems: combining LDA and HMM. First, LDA is used to perform theme modeling on massive heterogeneous scientific literature data. Then, the model is trained to generate themes and avoid efficiency and accuracy problems caused by manual labeling. The thematic change is discussed from the micro perspective of its heat and content changes through the introduction of HMM with double stochastic processes. Future research topics in the field of land degradation are predicted and visualized.

\section{Materials and Methods}

\subsection{Data Sources}

This study uses Web of Science as the data source, and the database is limited to the core collection of Web of Science. "TI=*land* and degradation" is used as the search formula [23,24], the document type is limited to "Article", and the search time is constrained to 1997-2020 (12 October 2020). The title, abstract, and publication time data of the literature in Excel format are downloaded. After deduplication, cleaning, and sorting steps, a total of 1395 studies were obtained. 


\subsection{Research Method}

\subsubsection{Thematic Extraction Module of Literature}

The main function of topic model is to extract an understandable and relatively stable latent semantic structure. The topic model adopts the bag-of-words method, which treats each literature as a word frequency vector, thereby transforming text information into mathematical information that is easy to model. The main assumption of topic modeling is that a series of themes connects a collection of words and documents, and themes can be understood as the probability distribution of words. LDA is a literature thematic generation model that uses a probabilistic generative process [34]. The LDA is also known as the three-layer Bayesian probability model, and it contains a three-layer structure of words, themes, and documents [35]. The model seeks clusters by maximizing the co-occurrence probability of words, introduces the Dirichlet prior distribution in the probabilistic latent semantic analysis to describe the document generation process, and limits the number of themes. This model solves the problems of overfitting of the Probabilitistic Latent Semantic Analysis model and many parameters to be estimated. Furthermore, the hidden themes of the documents can be efficiently extracted, and the documents can be clustered.

This study assumes that the themes of scientific literature follow the hyperparameter Dirichlet prior distribution:

$$
\operatorname{Dir}\left(\theta_{d} \mid \alpha\right)=\frac{\Gamma\left(\sum_{k=1}^{k} \alpha_{k}\right)}{\prod_{k=1}^{k} \Gamma\left(\alpha_{k}\right)} \prod_{k=1}^{k} \theta_{d k}^{\alpha_{k}-1}
$$

where $\theta_{d k}$ represents the distribution of scientific literature $d$ in theme $k$. This study generates thematic term distribution $\varnothing_{k} \sim \operatorname{Dir}(\beta)$ and $\theta_{d} \sim \operatorname{Dir}(\alpha)$ for themes $k$ and $d$, respectively. Moreover, this study generates thematic term $Z_{d n} \sim \operatorname{Multinomial}\left(\varnothing_{Z_{d n}}\right)$ for the $n$th term in each literature. Therefore, the LDA likelihood model in this article can be described as follows:

$$
p(W \mid \alpha, \beta)=\prod_{d=1}^{D} \int p\left(\theta_{d} \mid \alpha\right) \prod_{n=1}^{N_{d}} \sum_{Z_{d}} p\left(Z_{d n} \mid \theta_{d}\right) p\left(w_{d n} \mid \varnothing_{Z_{d n}}\right) d \theta_{d}
$$

The key to the dimensional reduction effect of LDA lies in the accurate setting of the number of potential themes in heterogeneous literature. However, the dimensional reduction effect and recognition rate of LDA are general. This situation is due to LDA that cannot effectively maintain local structural information under supervision. In addition, LDA cannot generate the optimal number of themes. Teh [36] tried to obtain the number of themes through nonparametric processing of Hierarchical Dirichlet Processes. However, this method is inefficient. The iterative accuracy of large-scale text analysis is difficult to ensure.

Scientific methods must be used to determine the optimal number of themes. Blei proposed using perplexity as a method to determine the optimal number of themes [37]. Perplexity is an effective way to evaluate the effects of language probability models and assist in parameter improvement. Based on information theory, this method calculates the probability distribution or the information entropy of the model and obtains the reciprocal of the geometric mean of the similarity of each sentence in the literature collection. This study uses this method to determine the optimal number of themes in the sample literature. The calculation formula of perplexity is:

$$
\begin{gathered}
\operatorname{Perplexity}(D)=\exp \left(-\frac{\sum_{d=1}^{M} \log _{D} P\left(w_{d}\right)}{\sum_{d=1}^{M} N_{d}}\right) \\
p\left(w_{d}\right)=\sum_{d} \prod_{n=1}^{T} \sum_{j=1}^{T} p\left(w_{j} \mid z_{j}=j\right) \cdot p\left(z_{j}=j \mid w_{d}\right) \cdot p(d)
\end{gathered}
$$


where $D$ represents the test set in the corpus, $\mathrm{M}$ represents the number of literature, $N_{d}$ represents the number of words in literature $d$, and $p\left(w_{d}\right)$ represents the probability of $w_{d}$ generation. Perplexity can quantitatively evaluate the performance of the LDA. When using perplexity for evaluation, the perplexity value will gradually decrease when many themes are present. However, the computational cost of the LDA is great when many themes are present. To avoid model overfitting, the selection of perplexity and the number of themes should be comprehensively considered. The smallest value with the perplexity and the least number of themes should be selected as the optimal number of themes for LDA model training.

Finally, this study adopts Heinrich's parameter estimation method, setting $\alpha=50 / k$, and $\beta=0.1$. This study also uses Gibbs sampling to obtain the theme set $K=\left\{k_{1}, \ldots, k_{h}\right\}$, and the theme attribution set $D_{k}=\left\{j_{1}, \ldots, j_{n}\right\}$ of each document.

\subsubsection{Literature Thematic Evolution Trend Analytical Module}

The two driving forces for the thematic evolution are as follows: the first one is the enlightenment that scholars receive through reading historical research results and the generation of new ideas during literature updating. However, this process is regarded as an unobservable hidden sequence due to the lack of record carrier. The second one is that under the first impetus, researchers use scientific literature to effectively record research results into observable sequences. The latter is the micro foundation of the former, and the former is the macro performance of the latter. Therefore, the thematic evolution of the land degradation research can be regarded as the superposition of two processes.

HMM is a probability statistical model established by Baum in 1966 [38]. This model was first used in the field of language processing and later popularized in other fields. In comparison with MM, HMM can express potential changes in the time series data structure through hidden states and recognize the transitions between hidden states, thus improving the adaptability and interpretation capabilities of the model. On this basis, this study uses HMM to describe the thematic evolution of the land degradation research. The confusion and transition matrixes between the themes are determined by inferring the state transition matrix in the HMM and the probability distribution of the initial state. The evolution history and future evolution trends of the themes in the field of land degradation are also determined. A complete HMM model can be described as a five-tuple: $\gamma=(S, \pi, A, B, O)$. On the basis of the above-mentioned ideas, this study constructs the HMM model as follows:

(1) The hidden state random transition sequence is: $S=\left\{s_{1}, \ldots, s_{h}\right\}$, where $h$ is the number of themes in the LDA model. Suppose the randomly generated hidden state sequence is $Q=\left\{q_{1}, \ldots, q_{t}\right\}$, where $q_{t} \in S$. Variable $t$ represents the number of themes in the hidden state. The modification in the hidden state represents the change in the state of the theme. Variable $Q$ is the sum of all possible theme states.

(2) The probability distribution of the initial state of the system is $\pi=\left\{\pi_{i}, 1 \leq i \leq N\right\}$, where $\pi_{i}$ is the occurrence probability of state $S_{i}$. In general, the thematic evolution easily occurs when the number of co-occurrences of themes in the field of land degradation is high. Therefore, the normalized matrix of the thematic co-occurrence number is used as the initial iteration value of $\pi_{i}$ in this study.

(3) The probability distribution of transition state is $A=\left\{\alpha_{i j}\right\}$, where $\alpha_{i j}$ $=P\left\{\left(q_{t+1}=S_{j} \mid q_{t}=S_{i}\right)\right\}, 1 \leq i$, and $j \leq N$, and satisfies $\alpha_{i j} \geq 0, \sum_{j=1}^{N} \alpha_{i j}=1$. This expression represents the probability that the themes will shift from state $S_{i}$ to $S_{j}$ during the development of the land degradation research.

(4) When the state is $S_{i}$, the probability distribution of the observed variable is $B=\left\{b_{i}(v)\right\}=\left\{f\left(Q_{t}=v \mid q_{t}=S_{i}\right)\right\}$, where $Q_{t}$ is the $t$ th observation variable.

(5) The observation sequence is $O=\left\{O_{1}, \ldots, O_{t}\right\}$. The observation value of a certain observation state sequence at time $t$ is $O_{t}$; it can be described as $O_{t}=(\alpha(t), \beta(t))$ in vector form. Variable $\alpha(t)$ represents the inflow frequency at time $t$, and $\beta(t)$ denotes the 
outflow frequency at time $t$. The vector sequence formed by the inflow and outflow of all observation samples can be regarded as observation state $O$. The above-mentioned model is shown in Figure 1.

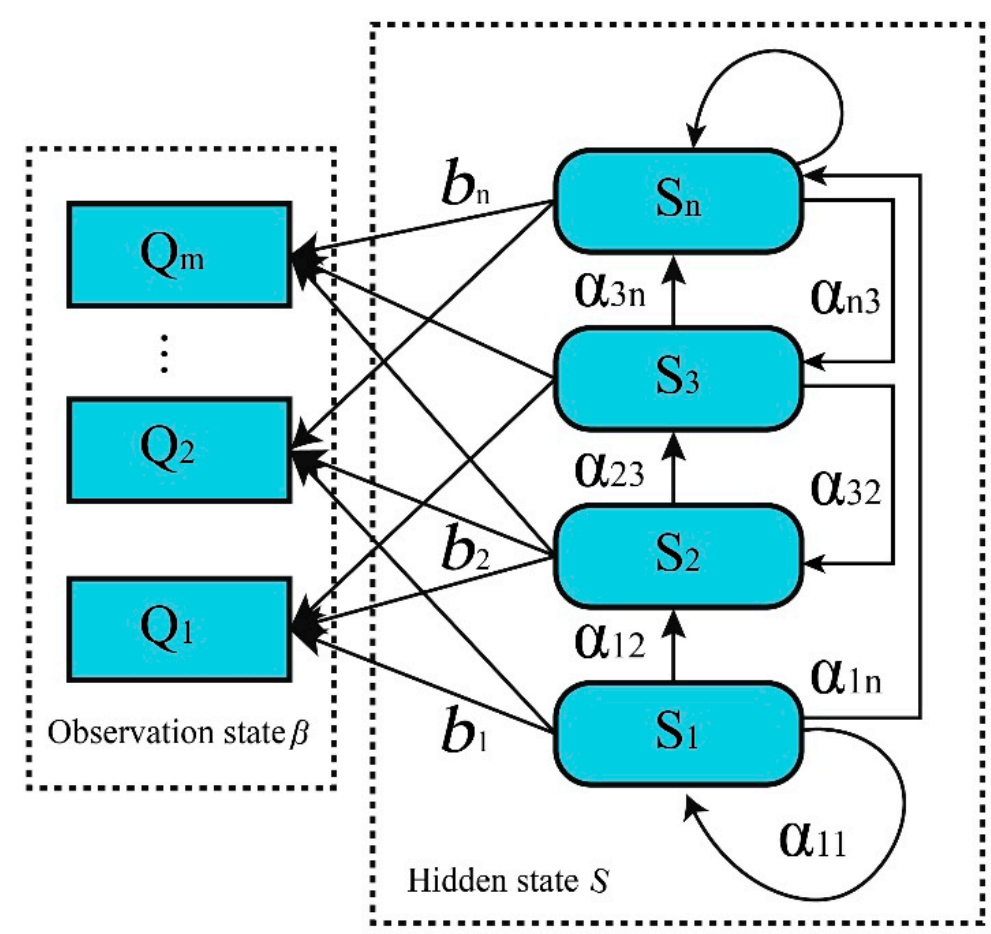

Figure 1. The relationship between hidden state transition sequence and observation sequence.

The initial value of model training is set as follows: $O=Q=\left\{p t_{1}, \ldots, p t_{2}\right\}$. The Baum-Welch algorithm is used to estimate the parameters of the above-mentioned model to obtain a single optimal state sequence. The research topic structure after $k$ years is obtained according to $\hat{O}_{t k}=\sum_{j=1}^{N} A^{K}(i, j) E\left(b_{j}(v)\right)$. The model setting in this work is shown in Figure 2.

\subsubsection{Thematic Extraction of Land Degradation Literature}

The LDA needs to set its operating parameters. First, the LDA is a machine learning algorithm, and its learning effect is closely related to the number of iterations. In this study, the contribution of new iterations to the increase in log likelihood approaches zero when the number of iterations reaches more than 300 . Considering the computational time cost, this study sets the number of iterations to 300 (Figure 3). This study calculated the perplexity value of 6 to 82 themes. When the number of themes is 27 , the perplexity is the smallest, and the value is 386.7168 (Figure 4). Thus, this study sets the number of themes to 27.

This study uses the LDA library in the Python database to calculate the thematic information and derive the keywords of each theme. Moreover, this study sets the number of keywords extracted under each theme to 40. Each keyword is outputted in a descending order of probability, and the keywords with the top five probability contained in each theme are selected as the meaning representative of the theme. Furthermore, this study combines the information provided by other output keyword and excludes clusters (4) with unclear meaning, leaving 23 themes. The boundaries between these themes are clear, and the classification results are ideal. This study names each theme for ease of reference, and the results are shown in Table 1. 


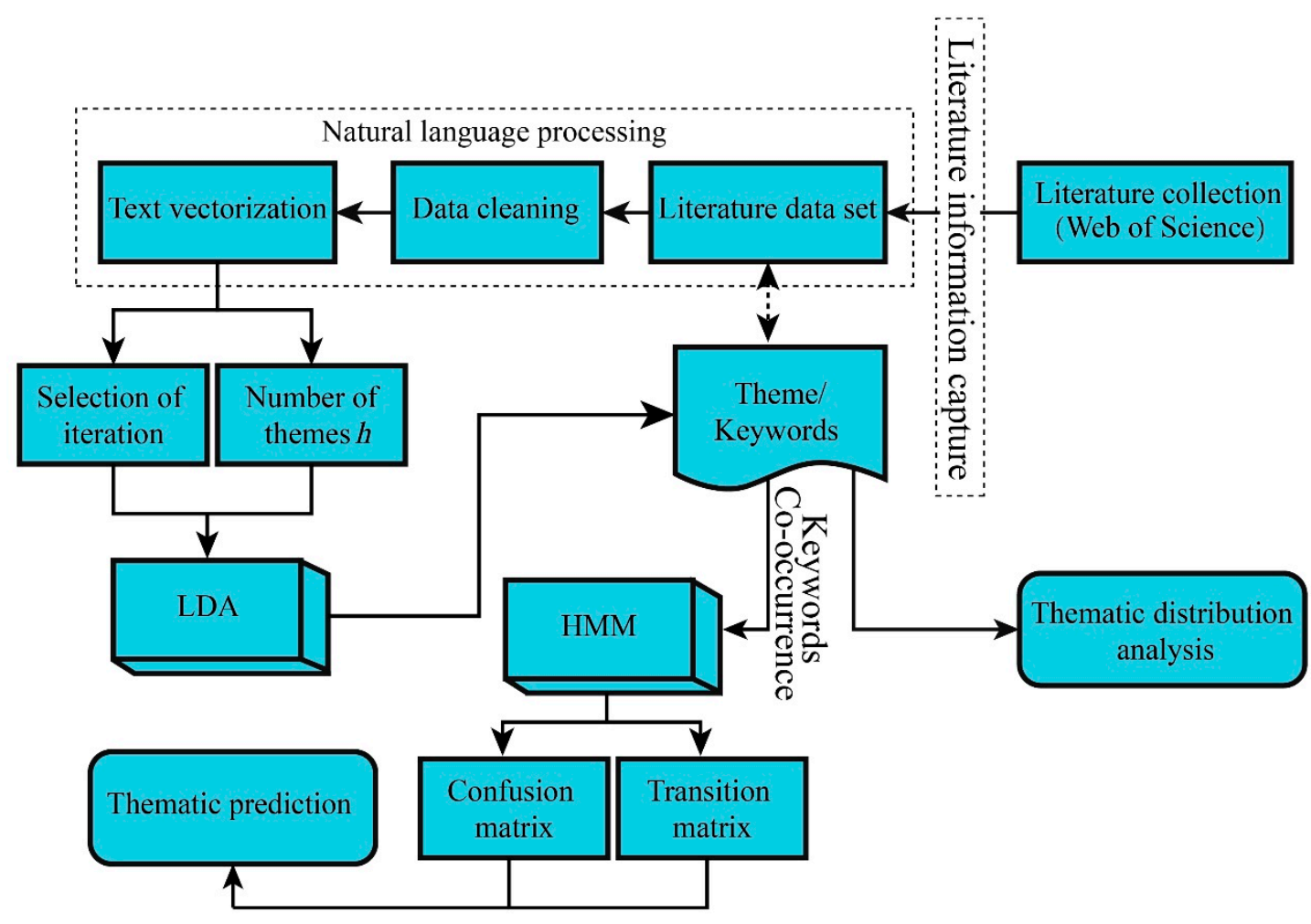

Figure 2. The flow chart of LDA-HMM.

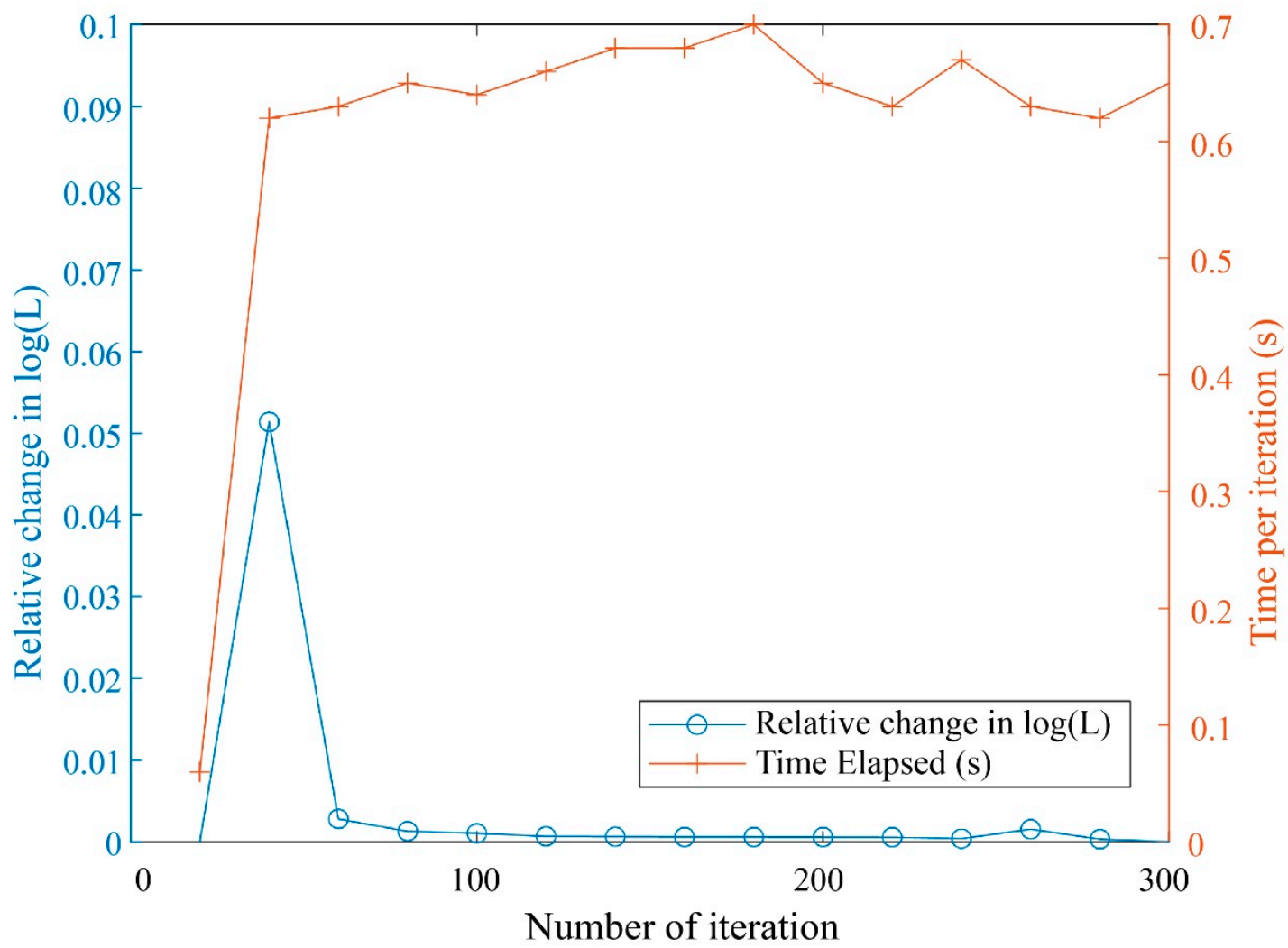

Figure 3. The impact of the number of iterations on the machine learning effect. 


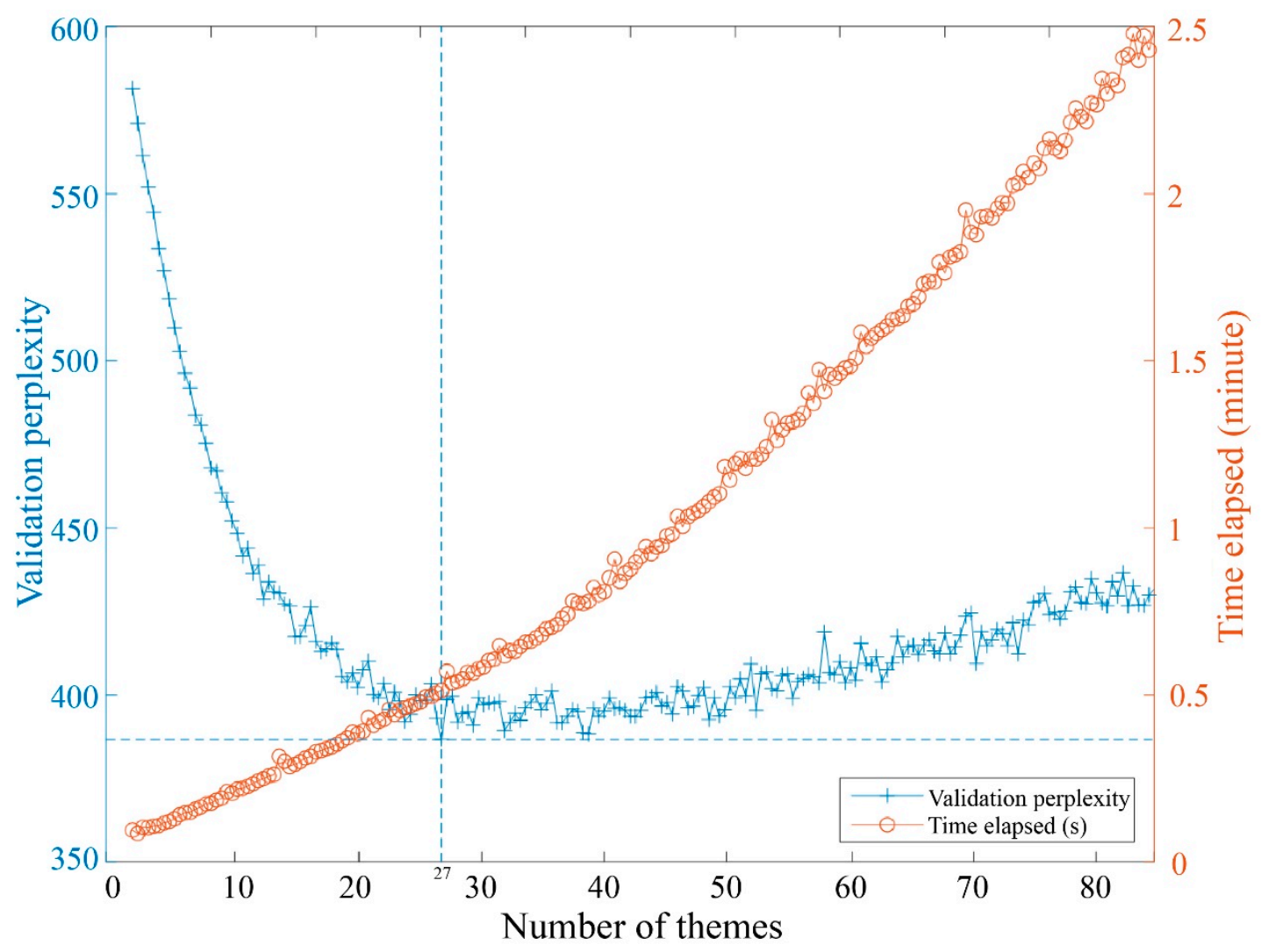

Figure 4. Perplexity values of different themes.

Table 1. Keywords and theme naming.

\begin{tabular}{|c|c|c|c|c|c|c|}
\hline No. & KW1 & KW2 & KW3 & KW4 & KW5 & ID \\
\hline 1 & land & degradation & change & region & result & land degradation \\
\hline 2 & degradation & environmental & analysis & present & regional & environmental degradation \\
\hline 3 & land & degradation & management & assessment & sustainable & sustainable land management \\
\hline 4 & vegetation & datum & degradation & index & trend & vegetation degradation \\
\hline 5 & agricultural & management & land & impact & farmer & agricultural land \\
\hline 6 & increase & region & population & year & influence & population increase \\
\hline 7 & degradation & activity & restoration & factor & study & restoration \\
\hline 8 & productivity & indicator & crop & high & per & crop productivity \\
\hline 9 & erosion & soil & risk & study & loss & soil erosion \\
\hline 10 & river & water & quality & natural & increase & water quality \\
\hline 11 & landscape & state & evaluate & assess & model & landscape model \\
\hline 12 & rainfall & period & zone & result & rate & rainfall rate \\
\hline 13 & soil & degradation & sample & content & microbial & soil degradation \\
\hline 14 & grassland & degradation & china & degrade & ecosystem & grassland degradation \\
\hline 15 & model & ecosystem & pattern & change & spatial & spatial change \\
\hline 16 & site & island & low & condition & decline & island \\
\hline 17 & degradation & temperature & effect & surface & result & surface temperature \\
\hline 18 & sediment & lake & year & fire & tree & lake sediment \\
\hline 19 & soil & carbon & organic & degrade & biomass & soil organic carbon \\
\hline 20 & wetland & degradation & flow & community & bacterial & wetland degradation \\
\hline 21 & rangeland & degradation & graze & ecological & condition & rangeland degradation \\
\hline 22 & plant & specie & vegetation & community & effect & plant species \\
\hline 23 & forest & deforestation & loss & stock & tropical & forest degradation \\
\hline
\end{tabular}

To evaluate the correctness of the LDA model for extracting themes in the field of land degradation, this study draws a sample of documents based on $10 \%$ of the number of documents in the topic, and the accuracy of each topic is shown in Figure 5. This study 
selects a sample of literature based on $10 \%$ of the number of literatures to evaluate the thematic accuracy (Figure 5). The average correct rate is $95.06 \%$, and the overall effect is good.

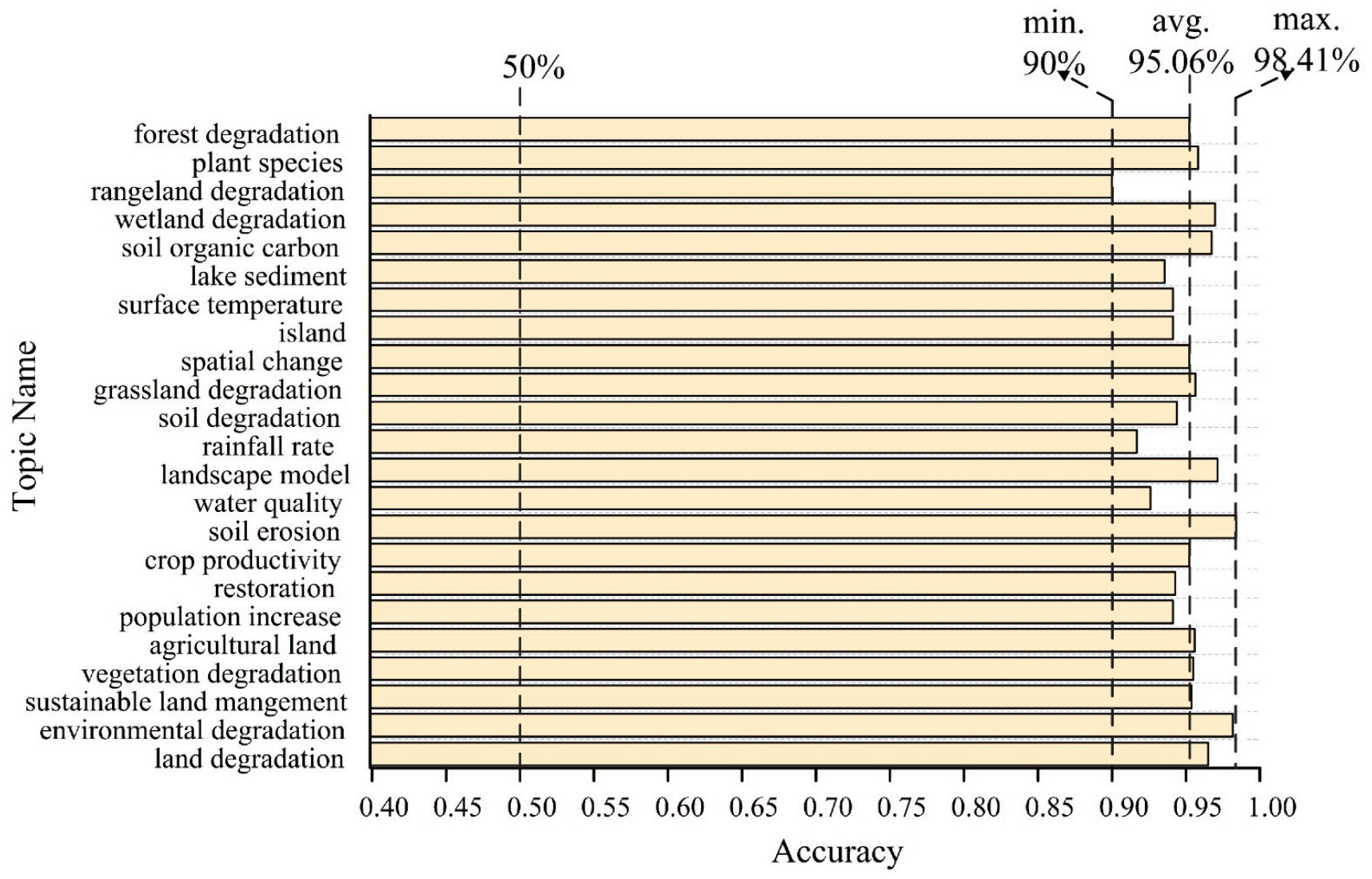

Figure 5. Accuracy of each thematic classification.

\section{Results and Analysis}

\subsection{Analysis of the Annual Development Trend of Themes in the Field of Land Degradation}

Based on the above-mentioned research results, this study draws the heat map of the number and percentage of themes in the field of land degradation (Figure 6). The theme will change accordingly over time. This change is reflected in the intensity and number of types. The thematic intensity reflects the degree of attention of the theme and also expresses the popularity of the theme in a certain field. The number of thematic types represents the breadth of themes that researchers are concerned about. The first appearance time and annual trend of the themes in the field of land degradation in Figure 6 demonstrated that the number of themes is gradually enriched and continuously subdivided. Only themes 2 (environmental degradation), 3 (sustainable land management), 4 (vegetation degradation), 5 (agricultural land), 8 (crop productivity), 12 (rainfall rate), 13 (soil degradation), 20 (wetland degradation), and 23 (forest degradation) existed in the early days (Figure 6b). The following are the three trends in the thematic evolution in the field land degradation after 2008: first, scholars are committed to studying the manner by which to effectively improve the level of sustainable land management. To take reasonable restoration measures for degraded land, the management and utilization of the land ecosystem are strengthened, and effective governance of the land structure and function is promoted. Zhang argued that the peatland degradation in Ruoergai area (China) is mainly due to drainage and overgrazing [39]. The author proposed that the establishment of blocking canals is an effective sustainable land management measure to restore the hydrological function of the degraded peatland and promote vegetation restoration. Second, the types of degraded land 
are diversified, such as grassland degradation (theme 14), wetland degradation (theme 20), rangeland degradation (theme 21), and forest degradation (theme 23).
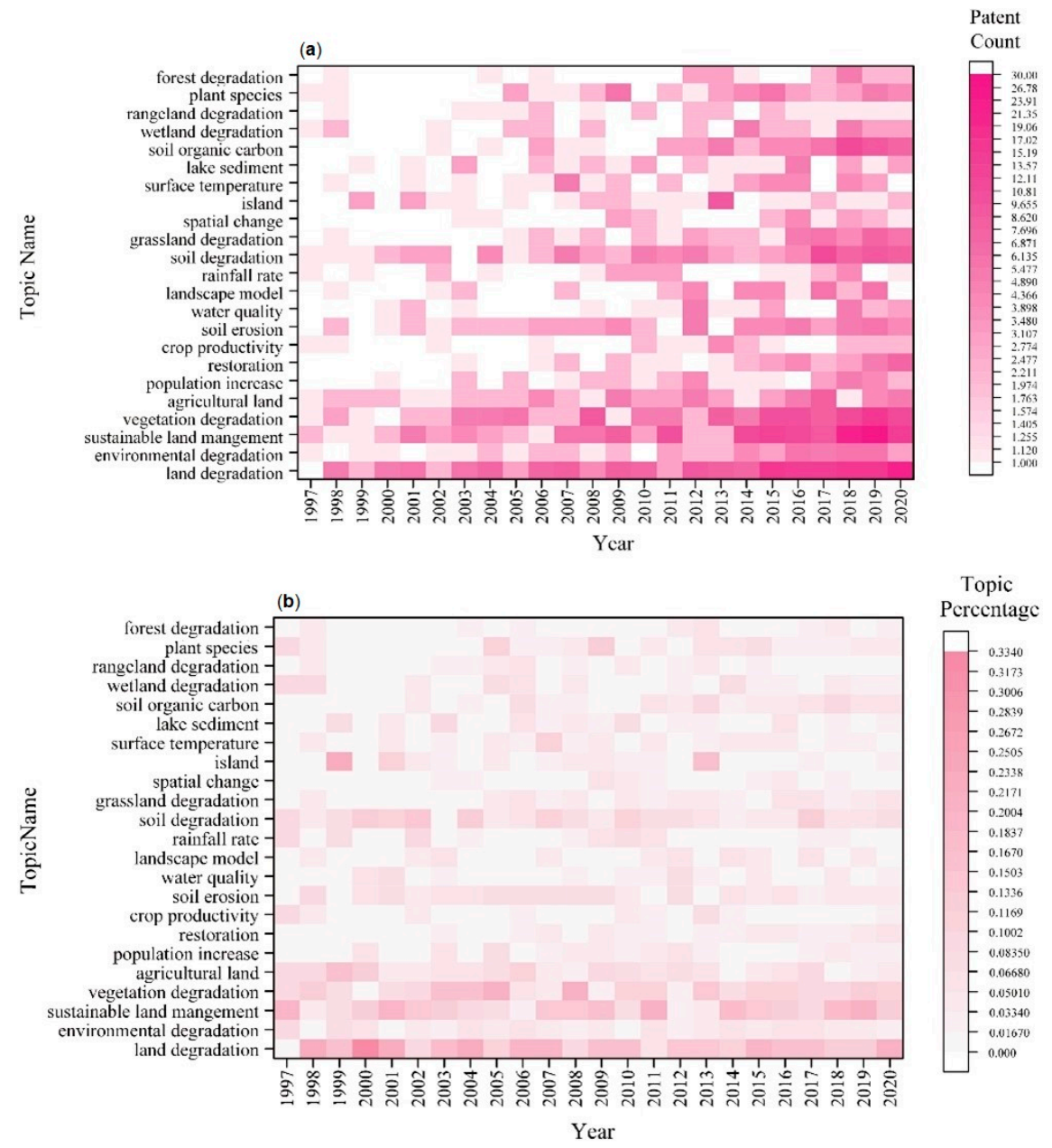

Figure 6. Evolutionary trend map of the number (a) and percentage (b) of each theme.

Figure 6a shows that the number of documents with the theme of "grassland degradation" has been increasing. The research interest has also been increasing in recent years. Grassland degradation is the process of degradation of grassland quality (including vegetation and soil quality) caused by human activities or unfavorable natural factors, reduction of productivity, economic potential and service functions, environmental degradation and reduction of biodiversity or complexity, and the reduction and loss of restoration functions [40]. This process not only affects the sustainable economic development of pastoral areas but also threatens the global ecological security. At present, scholars have conducted substantial research on the causes, mechanism, succession rules, management, monitoring, and evaluation of grassland degradation [41-44]. The third trend is to study the consequences of land degradation, such as changes in soil organic carbon [45], vegetation degradation [46], biodiversity reduced, increased river sediment concentration [47], and other adverse consequences. If scholars can correctly understand the causes and consequences of land degradation and conduct dynamic, effective, and quantitative monitoring and evaluation of land degradation within the region, then the degradation information can be quickly fed back and adjusted in time to achieve the ecological protection and sustainable development of land in a certain area. 


\subsection{Analysis on the Evolutionary Path of the Themes in the Field of Land Degradation}

If the keywords are similar between themes, then the probability of confusion or transition between themes is high. In view of this idea, this study adopts the keyword cooccurrence analytical method and counts the co-occurrence frequency of 40 main keywords in 23 themes as the representation of the similarity between themes. On this basis, this study constructs a $23 \times 23$ symmetric matrix of co-occurrence words and draws a heat map (Figure 7a). Given that each theme has the highest degree of co-occurrence with itself, an obvious diagonal line can be observed, and the other areas have varying shades of color due to the different number of co-occurrence words. The normalized co-occurrence words matrix (Figure $7 \mathrm{~b}$ ) is used as the initial confusion matrix and transition matrix of the HMM model, and the Baum-Welch algorithm is used to obtain the optimal confusion matrix (Figure 7c) and optimal transition matrix (Figure 7d).

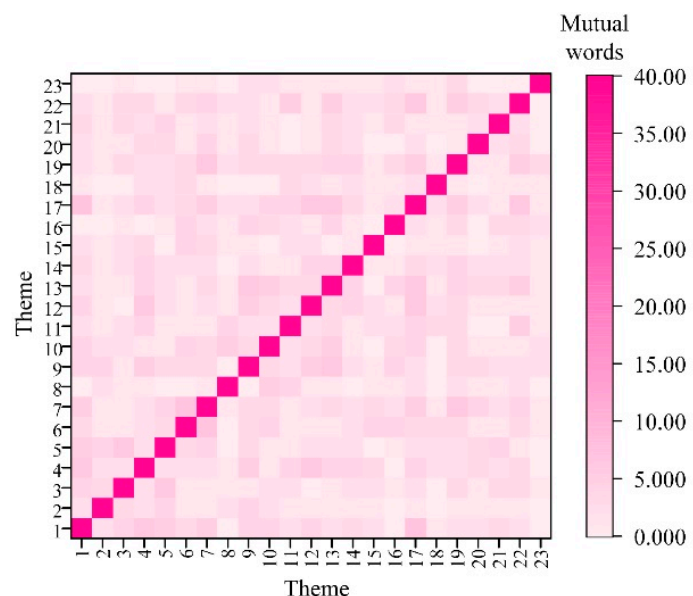

(a). Keywords co-occurrence matrix

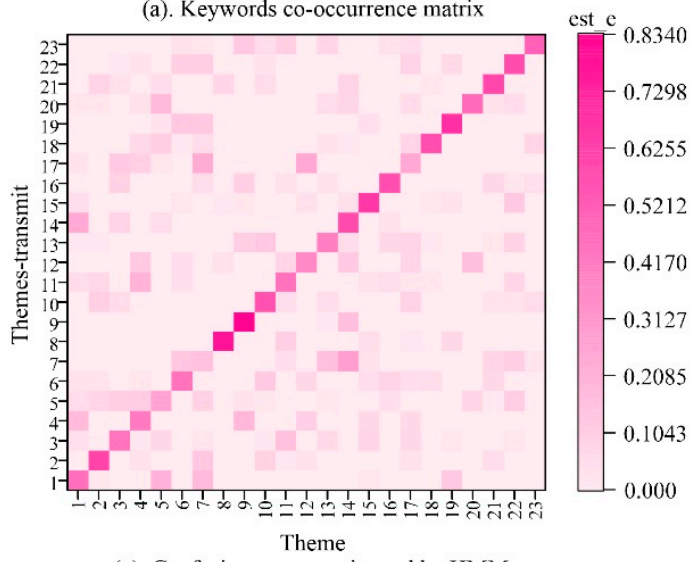

(c). Confusion matrix estimated by HMM

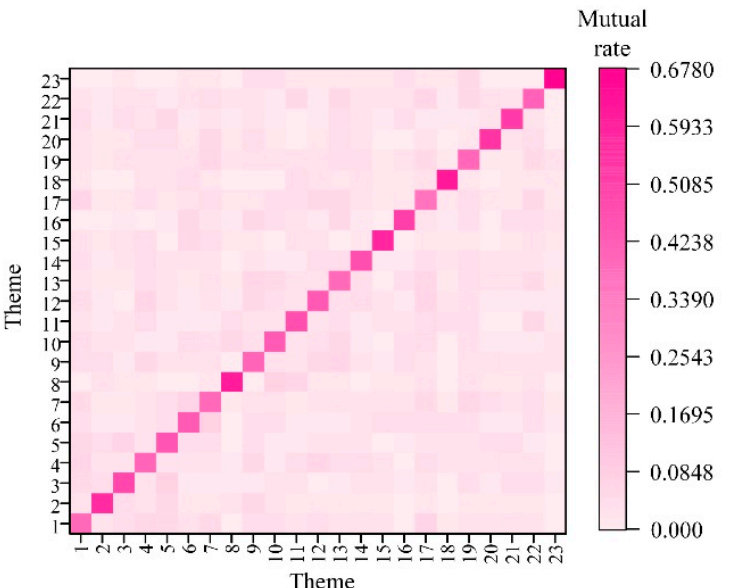

(b). Initial confusion matrix/Initial transition matrix

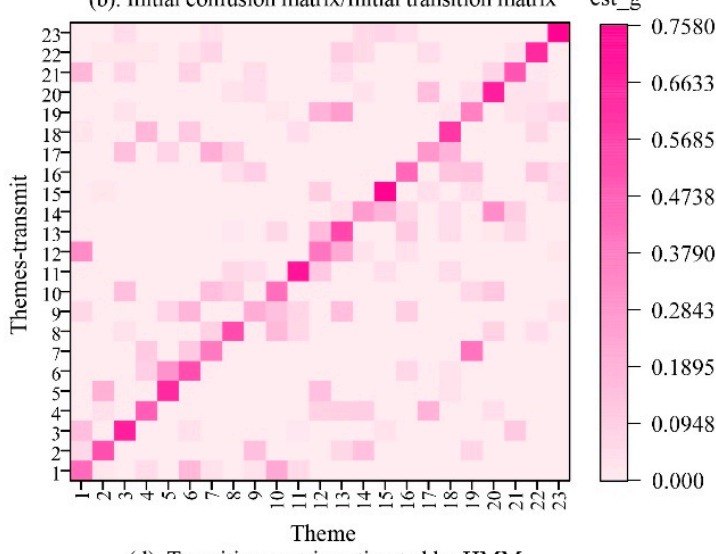

(d). Transition matrix estimated by HMM

Figure 7. Training process of HMM. Keywords co-occurrence matrix (a); Initial confusion matrix/Initial transition matrix (b); Confusion matrix estimated by HMM (c); Transition matrix estimated by HMM (d).

The confusion matrix represents the probability that the hidden state can be observed as the observable state. In this study, this probability is used to measure the threshold barriers for the transfer of themes in the field of land degradation in the evolutionary process. This study also shows the direction and possibility of a certain theme changing during the evolutionary process. The dark squares in the confusion matrix represent themes that are prone to migration during the evolutionary process. Figure $7 \mathrm{c}$ demonstrates that most themes in the field of land degradation have the characteristics of little confusion, relatively independent research content, and high threshold for migration. Specifically, barriers exist between most themes, and transfer is difficult. In this study, the themes with probability of confusion exceeding $10 \%$ are drawn as confusion relationship network diagram (Figure 8), where the thickness of the line represents the likelihood of confusion. 


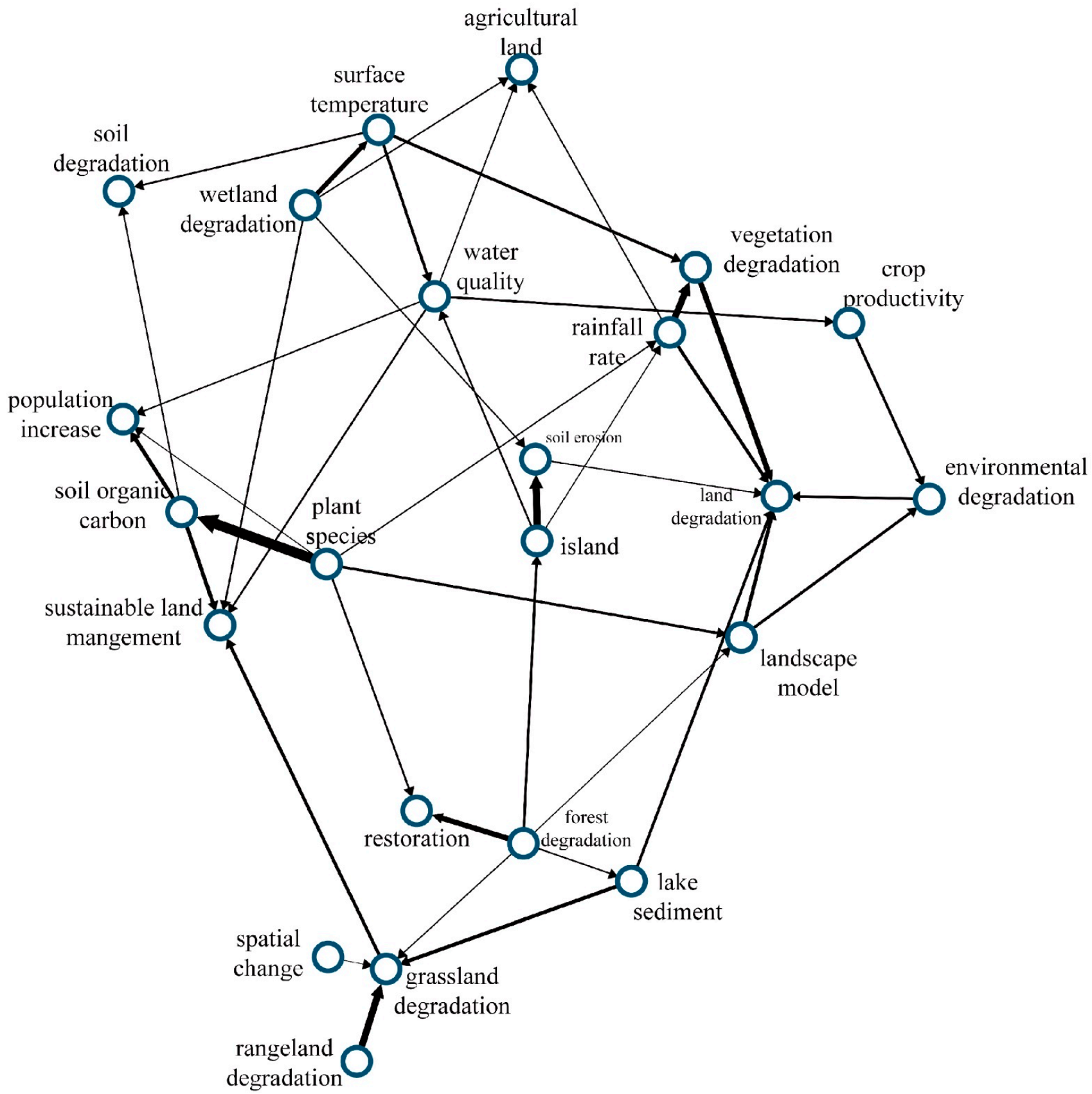

Figure 8. Confusion relationship network diagram between themes.

Figure 8 shows that the theme in the field of land degradation is easy to transfer to themes related to different land use types (such as agriculture land and grassland degradation) and land consolidation (such as sustainable land management and restoration). Many themes are transferred to population increase (theme 6). Rapid population growth, accelerated urbanization, and unreasonable human activities play an important role during land degradation [48]. The reason is that population growth, dietary changes, and increased income have increased the demand for livestock products in countries around the world, resulting in large-scale pasture expansion, which has led to grassland degradation and intensified land desertification [49]. In many developing countries, people have to increase the scale of cultivated land to maintain their livelihoods due to the dual pressures of population expansion and economic poverty. A large amount of forest land has been reclaimed into cultivated land, which has caused ecological environmental degradation. Specifi- 
cally, a vicious circle of "population expansion-poverty-cultivated land expansion-land degradation-poverty" is formed [50].

In addition, some research themes have important mediating roles in the thematic evolution and are key links in the development and changes of themes. For example, the landscape model provides technical support for exploring grassland degradation and changes of plant species. The landscape model is the mathematical model developed to simulate the spatial-temporal changes of the ecosystem at the landscape scale, and it is a technology that is reflected and tested on the computer. This mechanism has become an important technical means to support the quantitative development of landscape ecology [51]. The essence of land degradation is the change of landscape structure. The landscape model can not only quantitatively describe and predict the change trend of the composition, structure, and function of the land type at the landscape scale but also explain the changes in the spatial geographic area and distribution boundaries of the main plant population. Therefore, this model can be widely used in many fields, such as monitoring and research on vegetation, landscape and land change, resource management, and ecological environmental evaluation $[52,53]$. Another example is soil erosion, which is the key node and main reason for wetland degradation and island degradation. This phenomenon occurs because human disturbance activities will affect the physical and chemical properties of the wetland surface soil, leading to the attenuation of soil nutrients, weakening the ecological functions of the soil sub-system, and resulting in wetland degradation. Other themes that play similar role include rainfall rate, surface temperature, and water quality. The confusion feature of the themes reveals the potential evolutionary path of the themes in the field of land degradation and can provide scientific references for scientific research institutions to determine future research directions.

The transition matrix represents the probability of transition between themes. In summary, the diagonal line in Figure 7d is still relatively obvious, indicating that most themes have the stability to maintain their own research trends. From a single theme perspective, several differences can be observed in the transfer characteristics between themes. This study draws a thematic evolution diagram for themes with transition probability greater than 5\% (Figure 9). The themes that maintain their own strong research capabilities during the thematic evolution include: spatial change (0.75684), forest degradation (0.75085), and water quality (0.69955). The above-mentioned themes have maintained a high degree of popularity during the evolutionary process, and they are the key research nodes in the development of the land degradation research.

In addition, the theme with the largest transfer loss during the thematic evolution is rangeland degradation. This theme mainly flows to vegetation degradation, rainfall rate, soil erosion, and agricultural land. This situation occurs because soil moisture carries the circulation and flow of nutrients in the soil system, which is the primary factor for vegetation restoration and construction and determines the occurrence or reversal of rangeland degradation. Therefore, soil moisture is the research topic in the field of ecology, soil science, and eco-hydrology. Rainfall characteristics and vegetation coverage have a significant influence on soil moisture. On the one hand, rainfall is the main source of soil moisture. Rainfall is converted into soil water to be absorbed by plants and used to complete a series of life activities, such as respiration, transpiration, and photosynthesis. Therefore, the study of the response of soil moisture to different rainfall characteristics is an important prerequisite for predicting and improving the productivity in pastoral areas and preventing grassland desertification [54]. On the other hand, vegetation cover is an effective measure to suppress evaporation after rain, improve soil moisture environment, and increase crop yield and water use efficiency [55].

However, the current degradation of vegetation ecosystems has led to change in soil structure, increase in soil temperature and humidity, change in community structure and species composition, serious loss soil organic carbon and total nitrogen, reduction in soil water holding capacity, and significantly degradation of ecosystem stability. In view of this, scholars are currently devoted to exploring the response process and trend 
of soil environmental changes to vegetation degradation. This task not only helps in fully understanding the relationship between the two themes but also provides prevention and control measures for avoiding soil erosion and desertification [56,57]. The two research themes that have received great attention are land degradation and vegetation degradation. The research power of vegetation degradation mainly comes from rangeland degradation, lake sediment, surface temperature, rainfall rate, and soil erosion.

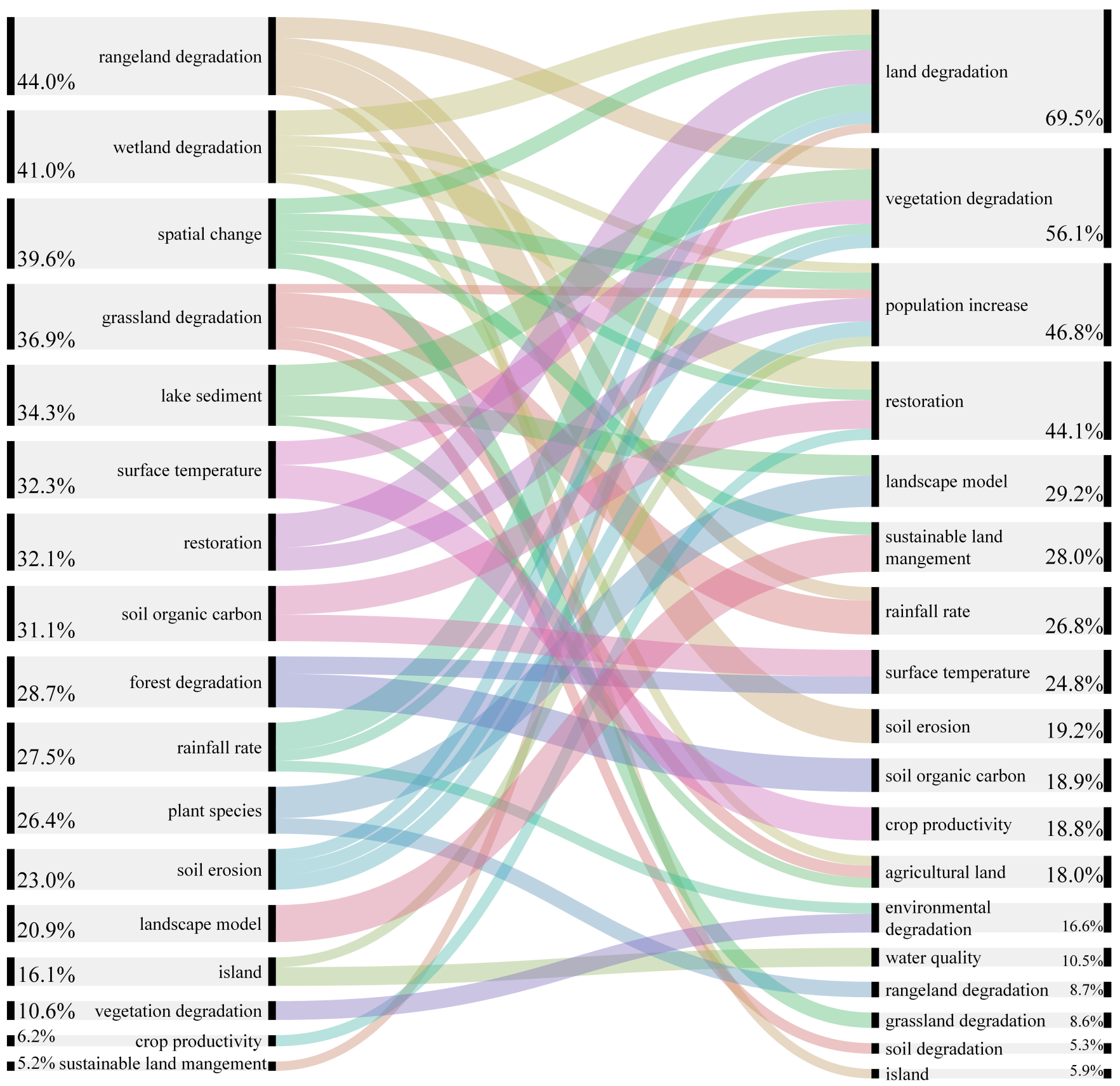

Figure 9. Hidden Markov estimates the transition probability between themes.

The relationship between surface temperature and vegetation is a mutual influence. On the one hand, surface temperature, an important parameter of energy exchange between land and atmosphere, plays an important role in the physical, chemical, biological, and microbial changes of soil. Therefore, this parameter has a significant influence on the germination of plant seeds and the growth of plants. On the other hand, vegetation is an important part of the regional ecosystem, and its influence on the surface temperature is 
manifold. First, the vegetation absorbs part of the solar radiation, thereby reducing the amount of heat that enters the epipedon and raises the ground temperature. In addition, vegetation can reduce surface wind speed and the evaporation of surface soil moisture and the intensity of heat release to the atmosphere. Vegetation also affects the energy balance of the surface through transpiration and plays an important role in the regulation of regional climate. At present, scholars have generally confirmed a negative correlation between vegetation coverage and surface temperature $[58,59]$. Therefore, preventing vegetation degradation and reducing surface temperature are of great significance to improving the regional ecological environment. The transfer process of these research themes shows the historical changes of different research directions in the field of land degradation and can provide basis for predicting the future development of themes.

\subsection{Forecast on the Thematic Evolution in the Field of Land Degradation}

Given that this article is still in progress, all documents on land degradation in 2020 are yet to be fully published. In the prediction of the future evolutionary trend of the themes in the field of land degradation, this study uses the 2019 document set as the forecast sample and imports the estimated confusion matrix and transition matrix parameters into the HMM module in MATLAB. This study also obtains the Hidden Markov prediction result of the thematic evolution of land degradation research from 2019 to 2026 (Figure 10).

Hidden Markov predicts that the proportions of rangeland degradation, surface temperature, island, soil degradation, water quality, and crop productivity have rapidly increased. Goal 2 in the SDGs is to "eliminate hunger, achieve food security, improve nutritional status and promote sustainable agriculture". The goal proposes that agricultural productivity needs to be doubled by 2030, while land productivity and output must be increased, and soil quality must be gradually improved. At present, $\sim 40 \%$ of the global agricultural land degradation has caused a sharp decline in crop yields and $\sim 9 \%$ of the land can no longer be used for crop production [60]. However, deforestation, destruction of native vegetation, loss of animal and plant habitats, extreme weather, and unsustainable farmland and pasture management, especially intensive agriculture, have become important factors that cause serious land degradation and threaten food security [61]. In addition, the source of water pollution is not only the water body itself but also the human activities closely related to land use in the basin. On the one hand, agricultural nonpoint source pollution caused by irrational use of agricultural land has become the main source of surface water pollution [62]. On the other hand, urban land use change has a significant influence on the surface runoff and water quality. The rapid development of urbanization has led to an increase in the impervious area of urban areas, which has changed the spatial-temporal patterns of surface runoff and the balance of water volume, resulting in an increase in the runoff coefficient. The urban land use process will simplify the shape of the water area, thereby reducing its own ability to diffuse and degrade pollutants, such as Biochemical Oxygen Demand (BOD), Chemical Oxygen Demand (COD), Total Nitrogen (TN), and Total Phosphorus (TP) [63]. Therefore, the manner by which to increase food production and solve the problem of water pollution will be an important challenge facing sustainable land use in the future.

Land degradation is the result of the interaction between the pressure of the natural environment and the pressure of human activities. The two pressures drive each other to cause different types of land degradation. The implementation of sustainable land management measures such as land degradation restoration and ecological restoration at the global and national levels can not only curb the spread of various types of land degradation and desertification, but also have a long-term positive impact on the sustainable development of the international society, economy and ecological environment. There are six types of land degradation: suspected degradation [64], historical degradation [65], sensitive degradation [66], elastic degradation [67], continuous degradation [68], permanent degradation [69]. Among them, the suspected degradation and sensitive degradation appear to be degraded on the surface, but they are still in an undegraded state and can be 
prevented through land protection. The object of land protection is potentially degraded land [70]. Historical degradation may have lasted a long time, but it is easy to be mistaken for land that has not yet undergone degradation. Elastic degradation refers to the possibility of natural recovery when the external degradation pressure decreases. Continuous degradation and permanent degradation are the land degradation states defined by IPBES. Even if the pressure source of these two kinds of degradation is eliminated, if there is no human measures, the two cannot be restored to the original land state. In addition, a lot of manpower and funds are needed to restore to the original state and LDN.

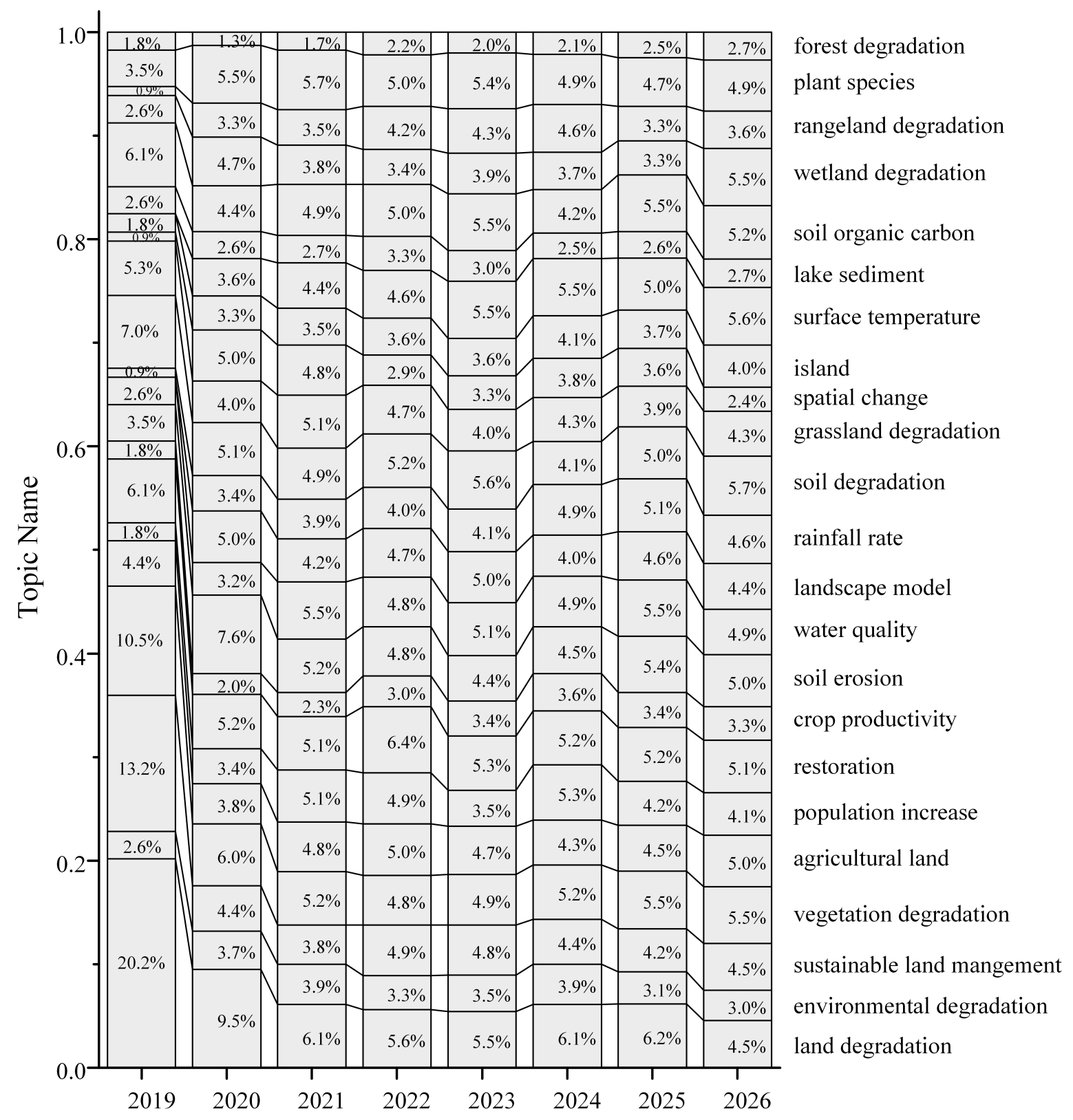

Figure 10. Forecast of thematic evolution trend from 2019 to 2026.

United Nations Convention to Combat Desertification (UNCCD) officially defined the concept of LDN in its official report published in 2015 as: under certain spatial-temporal scale and ecosystems, in order to maintain ecosystem functions and strengthen food security, the quantity and quality of corresponding land resources remain stable or increase. By focusing on the specific goal of "no net loss" in the quantity and quality of land, many measures have been taken to hinder, reduce and repair the deterioration of the 
land environment, and ultimately achieve food security, coordinated ecosystems, and healthy human development. This concept is similar to land degradation restoration and ecological restoration (see Table 2). The core goal of LDN and land restoration is not limited to improving the land ecological service function of a single goal, but is committed to ensuring that the total value of the overall land ecological service in the region is steadily increasing. More emphasis is placed on the optimization and overall improvement of ecological resource elements under the spatio-temporal pattern.

Therefore, restoration is still the main research direction in the field of land degradation. Land engineering can turn unutilized land into usable land or make efficient and sustainable utilization of used land. Therefore, land engineering technology plays an important role in promoting the improvement of cultivated land quality, degraded land management, waste land reuse, and land ecological restoration. At present, scholars in the field of land engineering generally pay attention to the green, ecological, sustainable development of land resources and the exploration of new technologies. The land reclamation that takes the damaged land as the research object and the innovation of vegetation restoration, reclamation materials, and reclamation technology as the main content [71]. land restoration with contaminated land as the research object, and multiple restoration technologies as the research content [72,73]. The above-mentioned two land types have become the focus of land degradation research.

Table 2. Analysis of the related concepts

\begin{tabular}{|c|c|c|c|c|}
\hline $\begin{array}{l}\text { The Name of } \\
\text { the Concept }\end{array}$ & Goal & Object & Research Scale & $\begin{array}{l}\text { Implementation } \\
\text { Measures }\end{array}$ \\
\hline LDN & $\begin{array}{l}\text { "No net loss" in land quantity } \\
\text { and quality }\end{array}$ & $\begin{array}{l}\text { Various ecosystems } \\
\text { and land use type }\end{array}$ & $\begin{array}{l}\text { The macro-scale is } \\
\text { based on the world, } \\
\text { regions and countries. }\end{array}$ & $\begin{array}{c}\text { Land space planning } \\
\text { and sustainable land } \\
\text { management }\end{array}$ \\
\hline $\begin{array}{c}\text { Land } \\
\text { degradation } \\
\text { restoration } \\
{[74,75]}\end{array}$ & $\begin{array}{l}\text { Ensure that the ecological } \\
\text { environment is structurally } \\
\text { complete and functionally } \\
\text { stable, and realize the benign } \\
\text { and healthy development of } \\
\text { the ecosystem }\end{array}$ & $\begin{array}{l}\text { Degraded, damaged, } \\
\text { destroyed and other } \\
\text { fragile land ecosystems }\end{array}$ & $\begin{array}{l}\text { From plot scale to } \\
\text { global scale }\end{array}$ & $\begin{array}{c}\text { Social, theoretical, } \\
\text { institutional, legal, } \\
\text { technical and } \\
\text { engineering measures. }\end{array}$ \\
\hline $\begin{array}{l}\text { Ecological } \\
\text { restoration } \\
{[76,77]}\end{array}$ & $\begin{array}{l}\text { Return the degraded or } \\
\text { damaged ecosystem to a stable, } \\
\text { healthy and sustainable } \\
\text { development state }\end{array}$ & $\begin{array}{l}\text { Various types of } \\
\text { ecosystems }\end{array}$ & $\begin{array}{l}\text { Small and medium } \\
\text { scale mainly based on } \\
\text { plots and regions }\end{array}$ & $\begin{array}{l}\text { Give play to the } \\
\text { self-organization and } \\
\text { self-regulation } \\
\text { capabilities of the } \\
\text { ecosystem }\end{array}$ \\
\hline
\end{tabular}

\subsection{Effect Evaluation of LDA-HMM}

This study uses the literature collection obtained in Section 2.1 to evaluate the effectiveness of the LDA-HMM method and Grey Forecast as an alternative method to obtain the evolutionary trend. The effects of the two mechanisms are compared. This study compares the LDA-HMM and LDA-Grey Forecast to obtain the average error between the predicted and the actual values of the thematic weight and measures the pros and cons of the two schemes. The results are shown in Table 3. The result showed that the average error of LDA-HMM is smaller than that of LDA-Grey Forecast, and the prediction effect is relatively good.

Table 3. Statistical table of average error of LDA-HMM and LDA-Grey Forecast.

\begin{tabular}{cc}
\hline Model Name & Average Error \\
\hline LDA-HMM & 0.0040 \\
LDA-Grey Forecast & 0.0078 \\
\hline
\end{tabular}




\section{Conclusions}

This study combines LDA and HMM to propose a new scientific literature thematic mining and prediction technology. In this way, this technology realizes efficient and unsupervised clustering of literature information without expert experience, quickly mines the hidden thematic information, obtains key thematic nodes and thematic evolution trend, and provides a new way for bibliometrics.

This method clusters the themes of the scientific literature in the field of land degradation into 23 themes. Among the themes, grassland degradation, sustainable land management, and restoration have been deeply studied. Research on themes, such as rangeland degradation, surface temperature, island, soil degradation, water quality, and crop productivity, is the focus of future research in the field of land degradation. However, the accumulation of scholars in these themes is still in its infancy, and innovation capabilities urgently need to be strengthened. How to conduct further innovative research on these research themes is the problem that scientific research institutions in various countries need to solve in the future.

The model comparison analytical results found that the clustering effect of LDA-HMM is good, and the average error is smaller than that of a similar thematic prediction method, which fully demonstrates the effectiveness and practicability of the research method in this study. In the future, the method can still be improved from the following aspects: further enhance the accuracy of thematic identification in scientific literature, reduce the complexity of the algorithm, and speed up the iterative efficiency to realize the analysis of larger-scale literature data sets.

Author Contributions: X.L., Y.Z. and C.L. conceptualized the research and performed the validation. X.L., Y.Z. and C.L. administered the project, developed the methodology, curated the data, conducted the formal analysis, produced visualizations, and wrote and prepared the original draft manuscript. Y.Z. C.L. and F.W. reviewed and edited the manuscript. X.L. acquired funding. All the authors contributed to drafting the manuscript. All authors have read and agreed to the published version of the manuscript.

Funding: This research is supported by the National Natural Science Foundation of China (NO. 71673096) and the National 985 Project of Non-traditional Security at Huazhong University of Science and Technology, P.R. China.

Acknowledgments: The authors would like to thank Jingwen Liao for her contribution to the photo editing in the article.

Conflicts of Interest: The authors declare no conflict of interest. 


\section{Appendix A}

Table 1. Key terms and their implication.

\begin{tabular}{|c|c|c|}
\hline Key Terms & Implication & References \\
\hline Land & $\begin{array}{l}\text { Land includes the atmosphere, soil, basic ge-ology, hydrology, plants, and animals above and below the } \\
\text { surface of a specific area of the Earth, as well as the results of past and present human activities within this } \\
\text { area. On the whole, land is a natural complex including geology, topography, climate, hydrology, soil, } \\
\text { vegeta-tion and other natural elements in a certain area of the surface. }\end{array}$ & {$[78]$} \\
\hline Land degradation & $\begin{array}{l}\text { Land degradation refers to a land condition caused by the continuous decline or even loss of biodiversity } \\
\text { and land ecosystem functions and services, and this condition cannot be fully recovered in a short period } \\
\text { of time. }\end{array}$ & {$[79,80]$} \\
\hline Soil erosion by water & $\begin{array}{l}\text { Soil erosion by water refers to the entire process of separation, migration and deposition of the Earth's } \\
\text { surface soil and its parent material under the effects of raindrop splash, surface runoff and infiltration water. }\end{array}$ & {$[81,82]$} \\
\hline Soil erosion by wind & $\begin{array}{l}\text { Soil erosion by wind refers to the process of positional movement of soil particles under the action of wind. } \\
\text { This movement process specifically includes three stages: entrainment of soil particles and sand, spatial } \\
\text { transport, and sedimentation. }\end{array}$ & {$[83,84]$} \\
\hline Land pollution & $\begin{array}{l}\text { Land pollution refers to the phenomenon and process in which certain harmful substances in the soil } \\
\text { exceed the normal content (invasion of mining waste, industrial waste or agricultural chemicals), which } \\
\text { deteriorates the original physical and chemical properties of the soil, reduces the potential of land } \\
\text { production, deteriorates the quality of products, and causes harm to humans and the environment. }\end{array}$ & {$[85,86]$} \\
\hline Landslides & $\begin{array}{l}\text { Landslide refers to the phenomenon that the soil or rock mass on the slope slides down the slope along the } \\
\text { weak surface or weak zone (affected by river erosion, groundwater activity, rainwater immersion, } \\
\text { earthquakes and artificial slope cutting). }\end{array}$ & {$[87,88]$} \\
\hline Soil acidification & $\begin{array}{l}\text { Soil acidification refers to the process in which the soil absorptive complex receives a certain amount of } \\
\text { exchangeable hydrogen ions or aluminum ions, which leads to the decrease of soil } \mathrm{pH} \text { and the leaching of } \\
\text { alkaline ions in the soil. Soil acidification will affect the activity of organisms in the soil, change the form of } \\
\text { nutrients in the soil, reduce the availability of nutrients, and promote the dissolution of free manganese and } \\
\text { aluminum ions into the soil solution, which has a toxic effect on crops. }\end{array}$ & {$[89,90]$} \\
\hline Soil organic carbon & $\begin{array}{l}\text { Soil organic carbon is the sum of humus, animal and plant residues and microorganisms formed by the } \\
\text { action of microorganisms. Soil degradation is the analysis of changes in soil physical, chemical and } \\
\text { biological indicators from a microscopic perspective, such as the loss of soil organic carbon and the decline } \\
\text { in water holding capacity. }\end{array}$ & {$[91,92]$} \\
\hline Waterlogging & $\begin{array}{l}\text { Waterlogging refers to the phenomenon of flooding of low-lying areas due to heavy rain, heavy rain or } \\
\text { continuous rainfall. }\end{array}$ & {$[93,94]$} \\
\hline Deforestation & $\begin{array}{l}\text { Deforestation refers to the felling of an area with a high density of trees by sawing or felling the trunk with } \\
\text { a saw or axe.Deforestation has the following adverse consequences: (1) destroy the original forest resources } \\
\text { (2) inability to conserve water sources, resulting in a decrease in river flow (3) increased drought and flood } \\
\text { damage (4) increased soil erosion (5) artificial exploitation of land after deforestation, resulting in the } \\
\text { accumulation of harmful ingredients such as herbicides and fertilizers, water pollution, and long-term } \\
\text { potential hazards. }\end{array}$ & {$[95,96]$} \\
\hline Overgrazing & $\begin{array}{l}\text { Overgrazing means that grazing exceeds the carrying capacity of the grassland, and the grassland plants } \\
\text { cannot return to their normal growth state, resulting in grassland degradation. }\end{array}$ & {$[97,98]$} \\
\hline $\begin{array}{l}\text { Agricultural } \\
\text { intensification }\end{array}$ & $\begin{array}{l}\text { Agricultural intensification refers to the investment of more labor, technology and capital per unit of land } \\
\text { area to increase agricultural output while reducing agricultural production costs. However, the } \\
\text { homogenization of the agricultural landscape brought about by the excessive agriculture intensification has } \\
\text { become the main reason for the decrease of farmland biodiversity. At the same time, excessive agricultural } \\
\text { intensification is also the main cause of non-point source pollution and changes in water quality. }\end{array}$ & {$[99,100]$} \\
\hline Aridity & $\begin{array}{l}\text { Aridity refers to a constant dryness in a given territory, assessed through an aridity index with climatic } \\
\text { values under the } 0.65 \mathrm{~mm} / \mathrm{mm} \text { threshold, computed as a ratio between precipitation and potential } \\
\text { evapotranspiration over a multiannual period of at least three decades. }\end{array}$ & [101-103] \\
\hline Desertification & Desertification refers to any land degradation process under aridity conditions. & {$[104,105]$} \\
\hline
\end{tabular}

\section{References}

1. Giuliani, G.; Mazzetti, P.; Santoro, M.; Nativi, S.; Van Bemmelen, J.; Colangeli, G.; Lehmann, A. Knowledge generation using satellite earth observations to support sustainable development goals (SDG): A use case on Land degradation. Int. J. Appl. Earth Obs. Geoinf. 2020, 88, 102068. [CrossRef]

2. Kotiaho, J.S.; Halme, P. The IPBES Assessment Report on Land Degradation and Restoration; IPBES Secretariat, UN Campus: Bonn, Germany, 2018; Available online: https:/ /ipbes.net/assessment-reports/ldr (accessed on 26 March 2018).

3. Gibbs, H.K.; Salmon, J.M. Mapping the world's degraded lands. Appl. Geogr. 2015, 57, 12-21. [CrossRef] 
4. Batunacun; Wieland, R.; Tobia, L.; Yunfeng, H.; Nendel, C. Identifying drivers of land degradation in Xilingol, China, between 1975 and 2015. Land Use Policy 2019, 83, 543-559. [CrossRef]

5. Gomiero, T. Soil Degradation, Land Scarcity and Food Security: Reviewing a Complex Challenge. Sustainability $2016,8,281$. [CrossRef]

6. Liu, K.; Huisingh, D.; Zhu, J.; Ma, Y.; O'Connor, D.; Hou, D. Farmers' perceptions and adaptation behaviours concerning land degradation: A theoretical framework and a case-study in the Qinghai-Tibetan Plateau of China. Land Degrad. Dev. 2018, 29, 2460-2471. [CrossRef]

7. Wilson, G.; Kelly, C.; Briassoulis, H.; Ferrara, A.; Quaranta, G.; Salvia, R.; Zhang, P. Social Memory and the Resilience of Communities Affected by Land Degradation. Land Degrad. Dev. 2017, 28, 383-400. [CrossRef]

8. Okpara, U.; Stringer, L.; Akhtar-Schuster, M. Gender and land degradation neutrality: A cross-country analysis to support more equitable practices. Land Degradation Development. Land Degrad. Dev. 2019, 30, 1368-1378. [CrossRef]

9. Collantes, V.; Kloos, K.; Henry, P.; Mboya, A.; Mor, T.; Metternicht, G. Moving towards a twin-agenda: Gender equality and land degradation neutrality. Environ. Sci. Policy 2018, 89, 247-253. [CrossRef]

10. Liniger, H.; Harari, N.; Van Lynden, G.; Fleiner, R.; De Leeuw, J.; Bai, Z.; Critchley, W. Achieving land degradation neutrality: The role of SLM knowledge in evidence-based decision-making. Environ. Sci. Policy 2019, 94, 123-134. [CrossRef]

11. Lorenz, K.; Lal, R.; Ehlers, K. Soil organic carbon stock as an indicator for monitoring land and soil degradation in relation to United Nations' Sustainable Development Goals. Land Degrad. Dev. 2019, 30, 824-838. [CrossRef]

12. Montana, J. Balancing authority and meaning in global environmental assessment: An analysis of organisational logics and modes in IPBES. Environ. Sci. Policy 2020, 112, 245-253. [CrossRef]

13. Borie, M.; Gustafsson, K.; Obermeister, N.; Turnhout, E.; Bridgewater, P. Institutionalising reflexivity? Transformative learning and the Intergovernmental science-policy Platform on Biodiversity and Ecosystem Services (IPBES). Environ. Sci. Policy 2020, 110, 71-76. [CrossRef]

14. Rukhovich, D.I.; Koroleva, P.V.; Rukhovich, D.D.; Kalinina, N.V. The Use of Deep Machine Learning for the Automated Selection of Remote Sensing Data for the Determination of Areas of Arable Land Degradation Processes Distribution. Remote Sens. 2021, 13, 155. [CrossRef]

15. Jiang, C.; Fan, W.; Yu, N.; Nan, Y. A New Method to Predict Gully Head Erosion in the Loess Plateau of China Based on SBAS-InSAR. Remote Sens. 2021, 13, 421. [CrossRef]

16. Díaz, S.; Pascual, U.; Stenseke, M.; Martín-López, B.; Watson, R.T.; Molnár, Z.; Shirayama, Y. Assessing nature's contributions to people. Science 2018, 359, 270-272. [CrossRef]

17. Okin, G.; D'Odorico, P.; Liu, J. A Mechanism of Land Degradation in Turf-Mantled Slopes of the Tibetan Plateau. Geophys. Res. Lett. 2018, 45, 4041-4048. [CrossRef]

18. Lyu, X.; Li, X.; Dang, D.; Dou, H.; Xuan, X.; Liu, S.; Gong, J. A new method for grassland degradation monitoring by vegetation species composition using hyperspectral remote sensing. Ecol. Indic. 2020, 114, 106310. [CrossRef]

19. Metternicht, G.; Akhtar-Schuster, M.; Castillo, V. Implementing land degradation neutrality: From policy challenges to policy opportunities for national sustainable development. Environ. Sci. Policy 2019, 100, 189-191. [CrossRef]

20. Raiesi, F.; Salek-Gilani, S. Development of a soil quality index for characterizing effects of land-use changes on degradation and ecological restoration of rangeland soils in a semi-arid. Land Degrad. Dev. 2020, 31, 1533-1544. [CrossRef]

21. Oliveira, E.; Tobias, S.; Hersperger, A.M. Can Strategic Spatial Planning Contribute to Land Degradation Reduction in Urban Regions? State of the Art and Future Research. Sustainability 2018, 10, 949. [CrossRef]

22. Halbac-Cotoara-Zamfir, R.; Smiraglia, D.; Quaranta, G.; Salvia, R.; Salvati, L.; Giménez-Morera, A. Land Degradation and Mitigation Policies in the Mediterranean Region: A Brief Commentary. Sustainability 2020, 12, 8313. [CrossRef]

23. Xie, H.; Zhang, Y.; Wu, Z.; Lv, T. A Bibliometric Analysis on Land Degradation: Current Status, Development, and Future Directions. Land 2020, 9, 28. [CrossRef]

24. Escadafal, R.; Barbero-Sierra, C.; Exbrayat, W.; Marques, M.; Akhtar-Schuster, M.; El Haddadi, A.; Ruiz, M. First Appraisal of the Current Structure of Research on Land and Soil Degradation as Evidenced by Bibliometric Analysis of Publications on Desertification. Land Degrad. Dev. 2015, 26, 413-422. [CrossRef]

25. Xie, H.; Zhang, Y.; Duan, K. Evolutionary overview of urban expansion based on bibliometric analysis in Web of Science from 1990 to 2019. Habitat Int. 2020, 95, 102100. [CrossRef]

26. Wang, K.; Feng, C.; Li, M.; Pei, Q.; Li, Y.; Zhu, H.; Tan, F. A bibliometric analysis of 23,492 publications on rectal cancer by machine learning: Basic medical research is needed. Ther. Adv. Gastroenterol. 2020, 13, 1-11. [CrossRef] [PubMed]

27. Zambrano, P.; Torres, J.; Tello-Oquendo, L.; Jacome, R.; Benalcazar, M.E.; Andrade, R.; Fuertes, W. Technical Mapping of the Grooming Anatomy Using Machine Learning Paradigms: An Information Security Approach. IEEE Access 2019, 7, 142129-142146. [CrossRef]

28. Martín, J.; Pagliara, F.; Román, C. The Research Topics on E-Grocery: Trends and Existing Gaps. Sustainability 2019, $11,321$. [CrossRef]

29. Lamba, M.; Madhusudhan, M. Mapping of topics in DESIDOC Journal of Library and Information Technology, India: A study. Scientometrics 2019, 120, 477-505. [CrossRef]

30. Zhang, Z.; Sun, W.; Yu, Y. Research on the Development of Marine Regional E-Commerce Based on the Analysis of Cloud Computing and Grey Prediction Method. J. Coast. Res. 2020, 115, 333-337. [CrossRef] 
31. Tsang, Y.; Wong, W.; Huang, G.; Wu, C.; Kuo, Y.; Choy, K. A Fuzzy-Based Product Life Cycle Prediction for Sustainable Development in the Electric Vehicle Industry. Energies 2020, 13, 3918. [CrossRef]

32. Wang, J.; Nie, G.; Xue, C. Landslide displacement prediction based on time series analysis and data assimilation with hydrological factors. Arab. J. Geosci. 2020, 13, 460. [CrossRef]

33. Almomani, F. Prediction the performance of multistage moving bed biological process using artificial neural network (ANN). Sci. Total Environ. 2020, 744, 140854. [CrossRef]

34. Ding, Y. Topic-based PageRank on author cocitation networks. J. Am. Soc. Inf. Sci. Technol. 2011, 62, 449-466. [CrossRef]

35. Blei, D.; Ng, A.; Jordan, M. Latent Dirichlet allocation. J. Mach. Learn. Res. 2003, 3, 993-1022.

36. Teh, Y.; Jordan, M.; Beal, M.; Blei, D. Sharing clusters among related groups: Hierarchical Dirichlet processes. Proc. Neural Inf. Process. Syst. Conf. 2005, 17, 1385-1392.

37. Blei, D. Probabilistic topic models. Commun. ACM 2012, 55, 77-84. [CrossRef]

38. Baum, L.; Petrie, T. Statistical Inference for Probabilistic Functions of Finite State Markov Chains. Ann. Math. Stat. 1996, 37, 554-1563. [CrossRef]

39. Zhang, X.; Liu, H.; Baker, C.; Graham, S. Restoration approaches used for degraded peatlands in Ruoergai (Zoige), Tibetan Plateau, China, for sustainable land management. Ecol. Eng. 2012, 38, 86-92. [CrossRef]

40. Liu, X.; Wang, Z.; Zheng, K.; Han, C.; Li, L.; Sheng, H.; Ma, Z. Changes in soil carbon and nitrogen stocks following degradation of alpine grasslands on the Qinghai-Tibetan Plateau: A meta-analysis. Land Degrad. Dev. 2020. [CrossRef]

41. Yang, Y.; Wang, J.; Chen, Y.; Cheng, F.; Liu, G.; He, Z. Remote-Sensing Monitoring of Grassland Degradation Based on the GDI in Shangri-La, China. Remote Sens. 2019, 11, 3030. [CrossRef]

42. Li, Y.; Liang, S.; Zhao, Y.; Li, W.; Wang, Y. Machine learning for the prediction of L. chinensis carbon, nitrogen and phosphorus contents and understanding of mechanisms underlying grassland degradation. J. Environ. Manag. 2017, 192, 116-123. [CrossRef]

43. Andrade, B.; Koch, C.; Boldrini, I.; Vélez-Martin, E.; Hasenack, H.; Hermann, J.-M.; Overbeck, G. Grassland degradation and restoration: A conceptual framework of stages and thresholds illustrated by southern Brazilian grasslands. Nat. Conserv. 2015, 13, 95-104. [CrossRef]

44. Cao, J.; Adamowski, J.F.; Deo, R.; Xu, X.; Gong, Y.; Feng, Q. Grassland Degradation on the Qinghai-Tibetan Plateau: Reevaluation of Causative Factors. Rangel. Ecol. Manag. 2019, 72, 988-995. [CrossRef]

45. Darwish, T.; Fadel, A. Mapping of soil organic carbon stock in the Arab countries to mitigate land degradation. Arab. J. Geosci 2017, 10, 474. [CrossRef]

46. Li, Q.; Zhou, D. Soil respiration versus vegetation degradation under the influence of three grazing regimes in the Songnen Plain Land Degrad. Dev. 2018, 29, 2403-2416. [CrossRef]

47. Lanckriet, S.; Asfaha, T.; Frankl, A.; Zenebe, A.; Nyssen, J. Sediment in Alluvial and Lacustrine Debris Fans as an Indicator for Land Degradation Around Lake Ashenge (Ethiopia). Land Degrad. Dev. 2015, 27, 258-269. [CrossRef]

48. Salvati, L. The spatial nexus between population growth and land degradation in a dry Mediterranean region: A rapidly changing pattern? Int. J. Sustain. Dev. World Ecol. 2011, 19, 81-88. [CrossRef]

49. Kosmas, C.; Detsis, V.; Karamesouti, M.; Kounalaki, K.; Vassiliou, P.; Salvati, L. Exploring Long-Term Impact of Grazing Management on Land Degradation in the Socio-Ecological System of Asteroussia Mountains, Greece. Land 2015, 4, 541-559. [CrossRef]

50. Mugizi, F.; Matsumoto, T. Population pressure and soil quality in Sub-Saharan Africa: Panel evidence from Kenya. Land Use Policy 2020, 94, 104499. [CrossRef]

51. Haga, C.; Inoue, T.; Hotta, W.; Shibata, R.; Hashimoto, S.; Kurokawa, H.; Shibata, H. Simulation of natural capital and ecosystem services in a watershed in Northern Japan focusing on the future underuse of nature: By linking forest landscape model and social scenarios. Sustain. Sci. 2018, 14, 89-106. [CrossRef]

52. Grinand, C.; Vieilledent, G.; Razafimbelo, T.; Rakotoarijaona, J.; Nourtier, M.; Bernoux, M. Landscape-scale spatial modelling of deforestation, land degradation and regeneration using machine learning tools. Land Degrad. Dev. 2019, 31, 1699-1712. [CrossRef]

53. Santos, D.; Souza, P.; Nascimento, W.; Cardoso, G.; Dos Santos, J. Land cover change, landscape degradation, and restoration along a railway line in the Amazon biome, Brazil. Land Degrad. Dev. 2019, 31, 2033-2046. [CrossRef]

54. Ziadat, F.; Taimeh, A. Effect of Rainfall Intensity, Slope, Land Use and Antechdent Soil Moisture on Soil Erosion in an Arid Environment. Land Degrad. Dev. 2013, 24, 582-590. [CrossRef]

55. Léonard, J.; Ancelin, O.; Ludwig, B.; Richard, G. Analysis of the dynamics of soil infiltrability of agricultural soils from continuous rainfall-runoff measurements on small plots. J. Hydrol. 2006, 326, 122-134. [CrossRef]

56. Xue, X.; You, Q.; Peng, F.; Dong, S.; Duan, H. Experimental Warming Aggravates Degradation-Induced Topsoil Drought in Alpine Meadows of the Qinghai-Tibetan Plateau. Land Degrad. Dev. 2017, 28, 2343-2353. [CrossRef]

57. Yan, M.; Cui, F.; Liu, Y.; Zhang, Z.; Zhang, J.; Ren, H.; Li, Z. Vegetation type and plant diversity affected soil carbon accumulation in a post-mining area in Shanxi province, China. Land Degrad. Dev. 2019, 31, 181-189. [CrossRef]

58. Yi, S.; Zhou, Z.; Ren, S.; Xu, M.; Qin, Y.; Chen, S.; Ye, B. Effects of permafrost degradation on alpine grassland in a semi-arid basin on the Qinghai-Tibetan Plateau. Environ. Res. Lett. 2011, 6, 045403. [CrossRef]

59. Thiebault, K.; Young, S. Snow cover change and its relationship with land surface temperature and vegetation in northeastern North America from 2000 to 2017. Int. J. Remote Sens. 2020, 41, 8453-8474. [CrossRef] 
60. Bossio, D.; Geheb, K.; Critchley, W. Managing water by managing land: Addressing land degradation to improve water productivity and rural livelihoods. Agric. Water Manag. 2010, 97, 536-542. [CrossRef]

61. Foley, J.A.; Ramankutty, N.; Brauman, K.A.; Cassidy, E.S.; Gerber, J.S.; Johnston, M.; Mueller, N.D.; O'Connell, C.; Ray, D.K.; West, P.C.; et al. Solutions for a cultivated planet. Nature 2011, 478, 337-342. [CrossRef]

62. Zinabu, E.; Kelderman, P.; van der Kwast, J.; Irvine, K. Evaluating the effect of diffuse and point source nutrient transfers on water quality in the Kombolcha River Basin, an industrializing Ethiopian catchment. Land Degrad. Dev. 2018, 29, 3366-3378. [CrossRef]

63. Hwang, S.; Lee, S.; Son, J.; Park, G.; Kim, S. Moderating effects of the geometry of reservoirs on the relation between urban land use and water quality. Landsc. Urban. Plan. 2007, 82, 175-183. [CrossRef]

64. Vagen, T.; Lal, R.; Singh, B. Soil carbon sequestration in sub-Saharan Africa: A review. Land Degrad. Dev. 2005, 16, 53-71. [CrossRef]

65. Valjavec, M.; Janza, M.; Smrekar, A. Environmental risk resulting from historical land degradation in alluvial plains considered for dam planning. Land Degrad. Dev. 2018, 29, 4227-4238. [CrossRef]

66. Kolios, S.; Mitrakos, S.; Stylios, C. Detection of areas susceptible to land degradation in Cyprus using remote sensed data and environmental quality indices. Land Degrad. Dev. 2018, 29, 2338-2350. [CrossRef]

67. Olsson, L.; Eklundh, L.; Ardoe, J. A recent greening of the Sahel-trends, patterns and potential causes. J. Arid. Environ. 2005, 63, 556-566. [CrossRef]

68. Wessels, K.; Prince, S.; Carroll, M.; Malherbe, J. Relevance of rangeland degradation in semiarid northeastern South Africa to the nonequilibrium theory. Ecol. Appl. 2007, 17, 815-827. [CrossRef]

69. Milton, S.; Dean, W.; du Plessis, M.; Sieg, W. A conceptual model of arid rangeland degradation. Bioscience 1994, 44, 70-76. [CrossRef]

70. Kurowska, K.; Kryszk, H.; Marks-Bielska, R.; Mika, M.; Len, P. Conversion of agricultural and forest land to other purposes in the context of land protection: Evidence from Polish experience. Land Use Policy 2020, 95, 104614. [CrossRef]

71. Ahirwal, J.; Kumar, A.; Pietrzykowski, M.; Maiti, S. Reclamation of coal mine spoil and its effect on Technosol quality and carbon sequestration: A case study from India. Environ. Sci. Pollut. Res. 2018, 25, 27992-28003. [CrossRef] [PubMed]

72. Komínková, D.; Fabbricino, M.; Gurung, B.; Race, M.; Tritto, C.; Ponzo, A. Sequential application of soil washing and phytoremediation in the land of fires. J. Environ. Manag. 2018, 206, 1081-1089. [CrossRef]

73. Ruthrof, K.; Fontaine, J.; Hopkins, A. Potassium amendment increases biomass and reduces heavy metal concentrations in Lablab purpureus after phosphate mining. Land Degrad. Dev. 2018, 29, 398-407. [CrossRef]

74. Venter, Z.; Scott, S.; Desmet, P.; Hoffman, M. Application of Landsat-derived vegetation trends over South Africa: Potential for monitoring land degradation and restoration. Ecol. Indic. 2020, 113, 106206. [CrossRef]

75. Sur, K.; Chauhan, P. Dynamic trend of land degradation/restoration along Indira Gandhi Canal command area in Jaisalmer District, Rajasthan, India: A case study. Environ. Earth Sci. 2019, 78, 472. [CrossRef]

76. Jiang, C.; Zhang, H.; Zhao, L.; Yang, Z.; Wang, X.; Yang, L.; Wen, M.; Geng, S.; Zeng, Q.; Wang, J. Unfolding the effectiveness of ecological restoration programs in combating land degradation: Achievements, causes, and implications. Sci. Total Environ. 2020, 748, 141552. [CrossRef]

77. Van der Heyde, M.; Bunce, M.; Dixon, K.; Wardell-Johnson, G.; White, N.; Nevill, P. Changes in soil microbial communities in post mine ecological restoration: Implications for monitoring using high throughput DNA sequencing. Sci. Total Environ. 2020, 749, 142262. [CrossRef] [PubMed]

78. Adnan, M.; Abdullah, A.; Dewan, A.; Hall, J. The effects of changing land use and flood hazard on poverty in coastal Bangladesh. Land Use Policy 2020, 99, 104868. [CrossRef]

79. Gilbey, B.; Davies, J.; Metternicht, G.; Magero, C. Taking Land Degradation Neutrality from concept to practice: Early reflections on LDN target setting and planning. Environ. Sci. Policy 2019, 100, 230-237. [CrossRef]

80. Keesstra, S.; Mol, G.; De Leeuw, J.; Okx, J.; Molenaar, C.; De Cleen, M.; Visser, S. Soil-Related Sustainable Development Goals: Four Concepts to Make Land Degradation Neutrality and Restoration Work. Land 2018, 7, 133. [CrossRef]

81. Rutebuka, J.; Munyeshuli, A.; Nkundwakazi, O.; Mbarushimana, D.; Mbonigaba, J.; Vermeir, P.; Verdoodt, A. Effectiveness of terracing techniques for controlling soil erosion by water in Rwanda. J. Environ. Manag. 2021, 277, 111369. [CrossRef] [PubMed]

82. Maltsev, K.; Yermolaev, O. Assessment of soil loss by water erosion in small river basins in Russia. Catena 2020, 195, 104726. [CrossRef]

83. Pi, H.; Huggins, D.; Sharratt, B. Soil wind erosion influenced by clay amendment in the inland Pacific Northwest, USA. Land Degrad. Dev. 2020, 32, 241-255. [CrossRef]

84. Ding, Z.; Zhang, Z.; Li, Y.; Zhang, L.; Zhang, K. Characteristics of magnetic susceptibility on cropland and pastureland slopes in an area influenced by both wind and water erosion and implications for soil redistribution patterns. Soil Tillage Res. 2020, 199, 104568. [CrossRef]

85. Lin, J.; Wu, Q.; Chen, R.; Tian, Z. A Novel Algorithm Based on 2-Additive Measure and Shapley Value and Its Application in Land Pollution Remediation. Math. Probl. Eng. 2020, 2020, 9323419. [CrossRef]

86. Jin, S.; Bluemling, B.; Mol, A. Mitigating land pollution through pesticide packages-The case of a collection scheme in Rural China. Sci. Total Environ. 2018, 622, 502-509. [CrossRef] [PubMed] 
87. Mohanty, A.; Hussain, M.; Mishra, M.; Kattel, D.; Pal, I. Exploring Community Resilience and Early Warning Solution for Flash Floods, Debris flow and Landslides in conflict prone villages of Badakhshan, Afghanistan. Int. J. Disaster Risk Reduct. 2018, 33, 5-15. [CrossRef]

88. Chudy, F.; Slamova, M.; Tomastik, J.; Tunak, D.; Kardos, M.; Salon, S. The application of civic technologies in a field survey of landslides. Land Degrad. Dev. 2018, 29, 1858-1870. [CrossRef]

89. Schlatter, D.; Kahl, K.; Carlson, B.; Huggins, D.; Paulitz, T. Soil acidification modifies soil depth-microbiome relationships in a no-till wheat cropping system. Soil Biol. Biochem. 2020, 149, 107939. [CrossRef]

90. Kimmel, K.; Furey, G.; Hobbie, S.; Isbell, F.; Tilman, D.; Reich, P. Diversity-dependent soil acidification under nitrogen enrichment constrains biomass productivity. Glob. Chang. Biol. 2020, 26, 6594-6603. [CrossRef] [PubMed]

91. Wuaden, C.; Nicoloso, R.; Barros, E.; Grave, R. Early adoption of no-till mitigates soil organic carbon and nitrogen losses due to land use change. Soil Tillage Res. 2020, 204, 104728. [CrossRef]

92. Abdalla, K.; Mutema, M.; Hill, T. Soil and organic carbon losses from varying land uses: A global meta-analysis. Geogr. Res. 2020, 58, 167-185. [CrossRef]

93. Minhas, P.; Yadav, R.; Bali, A. Perspectives on reviving waterlogged and saline soils through plantation forestry. Agric. Water Manag. 2020, 232, 106063. [CrossRef]

94. El Bastawesy, M.; Ali, R.; Al Harbi, K.; Faid, A. Impact of the geomorphology and soil management on the development of waterlogging in closed drainage basins of Egypt and Saudi Arabia. Environ. Earth Sci. 2013, 68, 1271-1283. [CrossRef]

95. Bos, A.; De Sy, V.; Duchelle, A.; Atmadja, S.; de Bruin, S.; Wunder, S.; Herold, M. Integrated assessment of deforestation drivers and their alignment with subnational climate change mitigation efforts. Environ. Earth Sci. 2013, 114, 352-365.

96. Mahari, W.; Azwar, E.; Li, Y.; Wang, Y.; Peng, W.; Ma, N.; Yang, H.; Rinklebe, J.; Lam, S.; Sonne, C. Deforestation of rainforests requires active use of UN's Sustainable Development Goals. Sci. Total Environ. 2020, 742, 140681. [CrossRef]

97. Nicu, I.C. Is Overgrazing Really Influencing Soil Erosion? Water 2018, 10, 1077. [CrossRef]

98. Fetzel, T.; Petridis, P.; Noll, D.; Singh, S.; Fischer-Kowalski, M. Reaching a socio-ecological tipping point: Overgrazing on the Greek island of Samothraki and the role of European agricultural policies. Land Use Policy 2018, 76, 21-28. [CrossRef]

99. Andersson Djurfeldt, A.; Hall, O.; Isinika, A.; Msuya, E.; Tambang Yengoh, G. Sustainable Agricultural Intensification in Four Tanzanian Villages-A View from the Ground and the Sky. Sustainability 2020, 12, 8304. [CrossRef]

100. Cerri, C.E.P.; Cerri, C.C.; Maia, S.M.F.; Cherubin, M.R.; Feigl, B.J.; Lal, R. Reducing Amazon Deforestation through Agricultural Intensification in the Cerrado for Advancing Food Security and Mitigating Climate Change. Sustainability 2018, 10, 989. [CrossRef]

101. Ayuso, S.; Onatibia, G.; Maestre, F.; Yahdjian, L. Grazing pressure interacts with aridity to determine the development and diversity of biological soil crusts in Patagonian rangelands. Land Degrad. Dev. 2019, 31, 488-499. [CrossRef]

102. Yan, C.; Yuan, Z.; Liu, Z.; Zhang, J.; Liu, K.; Shi, X.; Lock, T.R.; Kallenbach, R. Aridity stimulates responses of root production and turnover to warming but suppresses the responses to nitrogen addition in temperate grasslands of northern China. Sci. Total Environ. 2021, 753, 142018. [CrossRef]

103. Allen, R.; Dhungel, R.; Dhungana, B.; Huntington, J.; Kilic, A.; Morton, C. Conditioning point and gridded weather data under aridity conditions for calculation of reference evapotranspiration. Agric. Water Manag. 2020, 245, 106531. [CrossRef]

104. Zhai, X.; Yan, C.; Xing, X.; Jia, H.; Wei, X.; Feng, K. Spatial-temporal changes and driving forces of aeolian desertification of grassland in the Sanjiangyuan region from 1975 to 2015 based on the analysis of Landsat images. Environ. Monit. Assess. 2020, 193, 2. [CrossRef]

105. Gebru, B.; Lee, W.; Khamzina, A.; Wang, S.; Cha, S.; Song, C.; Lamchin, M. Spatiotemporal multi-index analysis of desertification in dry Afromontane forests of northern Ethiopia. Environ. Dev. Sustain. 2020, 23, 423-450. [CrossRef] 